\title{
EXCURSUS
}

\section{PROSOPOGRAPHY OF THE SENATORIAL ELITE FAMILIES}

The following pages discuss the senatorial elite families in detail. Their background, position before, during, and after the period AD 193 to 284, as well as relations with senators inside and outside their gens, are described both schematically and in a narrative account. The gens Caesonia is only described schematically here. Information on careers and relations is generally derived from PIR and PLRE, in which references to the primary sources can be found. Where other scholarly works supplement or correct PIR and PLRE, this is stated in footnotes.

\section{Table E1. The Acilii (Glabriones et Aviolae) ${ }^{1}$}

\author{
Cursus honorum - Consul ordinarius 210 with A. Triarius Rufinus \\ Notes \\ - Son of M'. Acilius Glabrio, consul II ordinarius 186 \\ (PIR A 69). \\ - Perhaps brother of Acilius Glabrio, clarissimus vir (Dig. \\ $4,4,18,1)^{2}$ \\ - Probably brother-in-law of Ti. Claudius Cleobulus, \\ consul suffectus early 3 rd century. ${ }^{3}$ \\ - Perhaps father of M'. Acilius Glabrio, consul ordinarius \\ $256 .^{4}$
}

\footnotetext{
${ }^{1}$ It cannot be determined with certainty whether the Acilii should be divided into two separate branches, the Aviolae and the Glabriones, or whether the Acilii were one branch using two cognomina simultaneously in the third century. On this problem, see Settipani (2000-2002), addenda I, 14-15. On the Acilii Glabriones, see also Dondin-Payre (1993); Jacques (1986), 152-155. See PIR ${ }^{2}$, pars I (1933), 12, for a stemma Glabrionum and, more recently, Settipani (2000), 198.

${ }^{2}$ Digesta 4, 4, 18, 1: (Acilius Glabrio) quem Severus et Antoninus non audierunt desiderantem restitui adversus fratrem. ('Indeed, the deified Severus and the emperor Antoninus did not hear Glabrio Acilius when, without alleging a reason, he sought restitutio against his brother after they had heard and determined his case' (trans. Watson)).

${ }^{3}$ Claudius Cleobulus was married to Acilia Frestana, who seems to have been Faustinus' sister. Settipani (2000), 189-191; Leunissen (1989), 191; Jacques (1986), 152. On the Claudii (Cleobuli), see Jacques (1986), 173.

${ }^{4}$ Leunissen (1989), 372.
} 
- Probably father-in-law of Claudius Acilius Cleobulus, who seems to have been his nephew. ${ }^{5}$

- Perhaps uncle of M'. Acilius Aviola, consul ordinarius $239 .^{6}$

M'. Acilius Aviola (PIR A 51)

Cursus honorum Notes

- Consul ordinarius 239 with Gordianus III

- Perhaps nephew of M'. Acilius Faustinus, consul ordinarius 210.

M('?). Acilius Glabrio 7 (PIR ${ }^{2}$ A 72)

Cursus honorum - Consul ordinarius 256 with L. Valerius Maximus (consul II)

- Proconsul Africae?? 3rd century?8

Notes

- Descendant (son?) of M'. Acilius Faustinus, consul ordinarius 210.

The patrician family of the Acilii, which was probably Italic and claimed descent from Aeneas, was politically engaged since the Republican period. ${ }^{9}$ The first Acilius whose consulship can be dated precisely was Gaius Calpurnius Acilius Aviola in AD 24. Members of the gens Acilia regularly held consulates during the first and second centuries AD. ${ }^{10}$

\footnotetext{
${ }^{5}$ CIL 09.2334 = ILS 1134 (Allifae, Italy) mentions Acilia Gabinia Frestana, daughter of Claudius Acilius Cleobulus and granddaughter of Acilius Faustinus. Cleobulus thus seems to have been married to a daughter of Acilius Faustinus. Settipani (2000), 189-190. Settipani suggests that the name Gabinia came from the girl's grandmother (Faustinus' wife) and adds that she was probably the daughter of C. Gabinius Barbarus Pompeianus, consul suffectus 194 and proconsul Asiae 212. This assumption, however, seems to lack evidential support and to be based on nomenclature only.

${ }^{6}$ According to Settipani (2000), 173 and 198.

7 Christol (1986), 99, points out that his praenomen appears on the inscription from Pisaurum (CIL 11.6335 = ILS 7218) as Marcus (M). However, one would expect Manius (M.), since he is probably a descendant of M'. Acilius Glabrio, consul II ordinarius 186, and M'. Acilius Faustinus, consul ordinarius 210.

${ }^{8}$ An Acilius Glabrio was governor of Africa, but the date of his appointment is disputable; it may alternatively have been in the second century AD. Thomasson (1996), 94, no. 132.

${ }^{9}$ On their Italic origin, see Dietz (1980), 352, who points out that the Acilii had properties in Allifae and Ostia. On the claim that the Acilii descended from Aeneas, see Herodianus, 2, 3, 3-4. According to Jacques (1986), 152, the Acilii entered the senate late third century $\mathrm{BC}$ and became patrician in the first century AD.

${ }_{10}$ M'. Acilius Aviola, consul ordinarius 54; M'. Acilius Glabrio, consul ordinarius 91; M'. Acilius Aviola, consul ordinarius 122; M'. Acilius Glabrio, consul ordinarius 124; M'. Acilius Glabrio Cn. Cornelius Severus, consul ordinarius 152; M'. Acilius Vibius Faustinus, consul suffectus 179; M'. Acilius Glabrio, consul suffectus circa 173, consul II ordinarius 186 . See Settipani (2000), 198.
} 
Three Acilii held the position of consul between AD 193 and 284, all as ordinarii. Acilius Faustinus was consul in 210, and is generally assumed to have been the son of Acilius Glabrio (PIR A 69), consul II ordinarius in 186 , who was highly honored in the senate by emperor Pertinax. ${ }^{11}$ Faustinus may have been the uncle of Acilius Aviola, consul in 239. Acilius Glabrio, consul in 256, may have been Faustinus' son. Yet, the interval of forty-six years between their consulates is quite long, especially within a patrician family whose members usually held consulates at a young age.

Aulus Triarius Rufinus, colleague of Acilius Faustinus in 210, was the son of Triarius Maternus signo Lascivius, consul ordinarius in 185. Acilius Glabrio's colleague in 256 was Lucius Valerius Maximus, representative of one of the other senatorial elite families of the third century, the Valerii (Messallae) (see below). Valerius Maximus' full name, Lucius Valerius Claudius Acilius Priscilianus Maximus, indicates that there may have been a connection between him and the Acilii. ${ }^{12}$ Acilius Aviola had an even more impressive colleague in 239: the emperor Gordianus III, who held his first consulship. As Dietz points out, the fact that Acilius Aviola was designated consul in the course of 238 , probably not long after Pupienus and Balbinus were killed, reveals that the influence of the high aristocracy did not decrease immediately after the deaths of these emperors. ${ }^{13}$

From 256 to 284 , there are very few indications that members of this family held consulates, proconsulates or the city prefecture: M'. Acilius Balbus Sabinus, who seems to have been connected to the gens, was probably consul suffectus under Diocletian, after 284. The same goes for Acilius Clarus. During the fourth century, no member of this family seems to have reached consular rank. The next consular Anicius seems

${ }_{11}$ Dio 74, 3, 3-4, mentions that Pertinax granted Acilius Glabrio (along with Claudius Pompeianus) the privilege to sit beside him in the senate, which was an exceptional honor. Herodianus 2, 3, 3-4, even states that Pertinax offered the imperial throne to Glabrio. Although the event was probably invented, it does reflect the high status of the gens Acilia in Herodianus' day. See also Champlin (1979), 289; 291-297, who states (295-296): '. . . in the early years of the sole rule of Commodus [...] Acilius Glabrio stood very close to the throne, both as counsellor and potential heir. In 193 he would stand with Claudius Pompeianus as the guardian of the dynasty and of legitimacy.'

12 Settipani (2000), 227-228, offers two hypotheses. First, that Valerius Maximus' father married a sister of M'. Acilius Faustinus, consul ordinarius 210. The other is that Valerius Maximus was a grandson of Ti. Claudius Cleobulus, consul suffectus early 3rd century, and Acilia Frestana, sister of Faustinus, consul ordinarius 210.

${ }^{13}$ Dietz (1980), 39. Acilius Aviola's consulate could also indicate that different factions existed among the high aristocracy and that his supported Gordianus III's against Pupienus and Balbinus. 
to have been Anicius Acilius Glabrio Faustus (PLRE I, Faustus 2), only in AD 438. His consulship seems to have been the beginning of a true revival of the Acilii as consular senators. At the end of the fifth century the Acilii provided their last consuls. ${ }^{14}$

Table E2. The Anicii ${ }^{15}$

\begin{tabular}{|c|c|}
\hline \multirow{5}{*}{ Cursus honorum } & Q. Anicius Faustus (PIR A 595) \\
\hline & - Legatus Aug(g?) pr pr Numidiae 197-201 \\
\hline & - Consul suffectus (in absentia) 198 \\
\hline & - Legatus Augg pr pr Moesiae Superioris 202?-205? \\
\hline & - Proconsul Asiae $217-219^{16}$ \\
\hline \multirow[t]{2}{*}{ Notes } & $\begin{array}{l}\text { - Probably father of Anicius Faustus Paulinus, consul } \\
\text { suffectus before } 230 .{ }^{17}\end{array}$ \\
\hline & $\begin{array}{l}\text { (Q. or Sex.?) Anicius Faustus Paulinus (PIR A } 596 \\
\text { and 599) }\end{array}$ \\
\hline \multirow[t]{2}{*}{ Cursus honorum } & - Consul suffectus before 230 \\
\hline & - Legatus Aug pr pr Moesiae Inferioris ca. 229/230 \\
\hline Notes & - Probably son of Q. Anicius Faustus, consul suffectus \\
\hline & $\begin{array}{l}\text { - Married to a daughter of Sex. Cocceius Vibianus }\left(P I R^{2}\right. \\
\text { C 1232), consul suffectus late } 2 \text { nd/early } 3 \text { rd century, } \\
\text { proconsul Africae early } 3 \text { rd century, or brother-in-law } \\
\text { of a son of this Cocceius Vibianus. }{ }^{18}\end{array}$ \\
\hline
\end{tabular}

${ }^{14}$ Settipani (2000-2002), add. I, 15-16, assumes that M'. Acilius Balbus Sabinus held a suffect consulship under Diocletian, based on the fact that he was curator alvei Tiberei circa 286/305. According to Jacques (1986), 153, an Acilius Clarus, vir consularis, praeses Numidiae (PLRE I, Clarus 2), may have been related to the gens as well. He has been identified with an Acilius Clarus, who was corrector Italiae in 286. Jacques, however, follows Arnheim and Christol, who suggest that the corrector was the father of the praeses of Numidia, whose position as praeses should then be dated somewhat later, circa 312320. Yet, it cannot be determined that an Acilius Clarus held a consulate before 284 . Neither can it be determined whether Acilius Severus, consul in 323, praefectus urbi 325326 (PLRE I, Severus 16), belonged to the same branch of Acilii or to a separate branch from Brixia. On this matter, see Jacques (1986), 154 no. 28, 155, and 99 where he speaks of a 'relativo offuscamento (relative obscurity)' of the gens in the fourth century. The other fifth-century consuls from the gens Acilia were Rufius Acilius Maecius Placidus, consul ordinarius 481; Anicius Acilius Aginantius Faustus, consul ordinarius 483; Rufius Acilius Sibidius, consul ordinarius 488. See Settipani (2000), 198.

15 See Corbier (1982), 741, for a stemma of the third-century Anicii. Alternative stemmata can be found in Settipani (2000), 348 and 432. PLRE I, 1133, stemma 7, lays out the Anicii from the mid-third century onward.

16 The dates of the positions mentioned here are based on Leunissen (1989), passim.

17 Leunissen (1989), 373.

18 Corbier (1982), 741, followed by Leunissen (1989), 166, note 165, thinks Paulinus married a daughter of Cocceius Vibianus. Settipani (2000), 348, on the other hand, thinks 
- Father (or uncle?) of M. Cocceius Anicius Faustus Flavianus, consul suffectus circa 250/252, and of Sex. Cocceius Anicius Faustus Paulinus, consul suffectus before $260 / 268$.

M. Cocceius Anicius Faustus Flavianus $\left(P I R^{2}\right.$

A 597/PLRE I, Flavianus 8)

\section{Cursus honorum}

Notes

\section{Cursus honorum}

Notes
- Curator rei publicae Cirtae 251

- Consul suffectus ca. 250/2

- Probably son (or nephew?) of Anicius Faustus Paulinus, consul suffectus before 230, and brother of Sex. Cocceius Anicius Faustus Paulinus, consul before $260 / 8 .^{19}$

- Patricius.

\section{Sex. Cocceius Anicius Faustus Paulinus $\left(P I R^{2}\right.$}

A 60o/PLRE I, Paulinus 16)

- Consul suffectus before $260 / 8$

- Proconsul Africae ca. 265/8 ${ }^{20}$

- Probably son (or nephew?) of Anicius Faustus Paulinus, consul suffectus before 230, and brother of M. Cocceius Anicius Faustus Flavianus, consul suffectus ca. $250 / 2$.

- Ancestor (father?) of Anicius Faustus (PLRE I, Faustus 6), consul II ordinarius 298 with Virius Gallus, praefectus urbi 299-300, and of Paulinus (PLRE I, Paulinus 2), consul ordinarius 277 with Probus (see above). ${ }^{21}$

- Claudia Sestia Cocceia Severina $\left(P I R^{2}\right.$ C 1123), wife of Q. Hedius Lollianus Plautius Avitus, consul ordinarius 209, may have been a relative. ${ }^{22}$

- At the end of the 3 rd or the beginning of the 4 th century, the Anicii seem to have become connected to the Caesonii. ${ }^{23}$

that a daughter of Anicius Faustus, consul suffectus 198, married a son of Sex. Cocceius Vibianus, and that Faustus' sons included M. Cocceius Anicius Faustus Flavianus, consul suffectus circa 250/252, and Cocceius Anicius Faustus Paulinus, consul before 260 / 268. For the moment, the exact lineage remains unclear.

${ }_{19}$ Novak (1976), 26; 56; Corbier (1982), 741.

20 According to Thomasson (1996), 92-93, although he admits that the appointment may also have taken place between 276 and 285 under Probus, Carinus or Carinus' sons.

${ }^{21}$ Christol (1986), 115 suggested that Cocceius Anicius Faustus Paulinus may have been their father. Cf. Settipani (2000), 347, note 8; 432.

22 According to PLRE I, Paulinus 16, 681. See also Settipani (2000), 406-407.

23 This assumption is based on the names of M. Iunius Caesonius Nicomachus Anicius Faustus Paulinus, praetor urbanus 321, and of Amnius Manius Caesonius Nicomachus Anicius Paulinus, consul 334, praefectus urbi 334-335. The fact that some Anicii in the 
The Anicii appear in the sources in the second century AD. Their geographical origin has been disputed. Some scholars consider them to have been notables from the African city Uzappa, while others think they originated from Praeneste in Italy. ${ }^{24}$

Anicius Faustus was the first member of the gens Anicia to become consul (suffectus) at the end of the second century. He may have been a homo novus. ${ }^{25}$ Anicius Faustus held his consulship in absentia while he was governor of Numidia, after which he became consular governor of Moesia Superior. This was the last position he held under Septimius Severus. For unknown reasons, the emperor refused to let him participate in the raffle for the governorships of the proconsular provinces. It was not until the reign of Macrinus that Anicius Faustus finally became governor of Asia, replacing Gaius Iulius Asper, who was recalled by Macrinus before he had even reached the province. ${ }^{26}$

An inscription which can be dated to AD 230 mentions Anicius Faustus Paulinus, probably the son of Anicius Faustus, as governor of Moesia Inferior. ${ }^{27}$ Since this was a consular position, it may be assumed that this man was consul suffectus prior to his governorship. Cocceius Anicius Faustus Flavianus, consul suffectus circa 250/2, and Cocceius Anicius Faustus Paulinus, proconsul Africae somewhere between 260 and 268, belong to the next generation of this family, a generation which somehow descended from the Cocceii. By that time, the family, which descended from a vir militaris, had reached patrician status. ${ }^{28}$ They are the last consular Anicii who can be assigned to the period under discussion with certainty.

fourth and fifth century bore the cognomen Bassus indicates that they may have been descendants of L. Caesonius Ovinius Manlius Rufinianus Bassus and his son Caesonius Bassus, consul 317. See Settipani (2000), 348 for a stemma, and 347, note 8 for an alternative suggested by Chausson.

${ }^{24}$ On their origin, see Corbier (1982), 740, and Leunissen (1989), 365.

25 Jacques (1986), 158.

${ }^{26}$ Dio 79, 22, 2-4. Novak (1976), 40-41, suggests that Faustus was a protégé of Plautianus and that this caused the lapse from favor after 205 and during the reign of Caracalla. Novak considers it significant that Faustus re-emerged under Macrinus, an underling of Plautianus. Novak (1976), 37-38: 'Macrinus allowed him to continue in office the following year, thereby displacing Aufidius Fronto, a descendant (son) of an honored Antonine general. Surely, Macrinus' offer of the salary instead of the post to Fronto should be construed as an insult. The novus homo Faustus in his place only intensified the sting.'

${ }^{27}$ CIL 3.7473 (Moesia Inferior).

${ }^{28} \mathrm{M}$. Cocceius Anicius Faustus Flavianus is called patricius in CIL 08, 07040 $=A E$ 1946, 61 = ILAlg 02, 01, 00625 (Numidia). Novak (1976), 55-56, suggests that this may 
Two other consulates are doubtful. An Anicius Faustus was consul iterum in 298. It is not unlikely that he held his first consulship before 284 , since an interval of circa twenty years between the first and second consulship was quite common. Furthermore, it has been suggested that Paulinus, consul ordinarius in 277 with the emperor Probus, belonged to the gens Anicia as well, and that he may have been the brother of the consul of 298. The Anicii continued to be an important consular family during the fourth century, and traceable even afterwards are consuls bearing this nomen. ${ }^{29}$

At the end of the third or beginning of the fourth century, the Anicii established relations with the Caesonii. They may have had relations with the Hedii as well. ${ }^{30}$

Table E3. The Bruttii ${ }^{31}$

\begin{tabular}{|c|c|}
\hline \multirow{3}{*}{$\begin{array}{l}\text { Cursus honorum } \\
\text { Notes }\end{array}$} & C. Bruttius Praesens (PIR ${ }^{2}$ B 166) \\
\hline & $\begin{array}{l}\text { - Consul ordinarius } 217 \text { with T. Messius Extricatus } \\
\text { - Grandson of C. Bruttius Praesens (PIR B 165), consul }\end{array}$ \\
\hline & $\begin{array}{l}\text { - Grandson of C. Bruttius Praesens (PIR }{ }^{2} \text { B 165), consul } \\
\text { II ordinarius } 180 \text {, comes of Marcus Aurelius and } \\
\text { Commodus in the expeditio Sarmatica } 173^{-175} \text { and } \\
\text { father-in-law of Commodus. } \\
\text { - Son of L. Bruttius Quintius Crispinus (PIR }{ }^{2} \text { B 169), } \\
\text { consul ordinarius } 187 \text {. } \\
\text { - Nephew of Crispina Augusta, Commodus' wife. } \\
\text { - Brother of C. Bruttius Crispinus, consul ordinarius } 224 . \\
\text { - Probably father of C. Bruttius Praesens, consul } \\
\text { ordinarius } 246 .\end{array}$ \\
\hline & $\begin{array}{l}\left.\text { C. (or L.?) Bruttius Crispinus (PIR }{ }^{2} \text { B } 160\right) \\
\text { - Consul ordinarius } 224 \text { with App. Claudius Iulianus }\end{array}$ \\
\hline otes & $\begin{array}{l}\text { - Son of L. Bruttius Quintius Crispinus, consul } \\
\text { ordinarius } 187 \text {. } \\
\text { - Brother of C. Bruttius Praesens, consul ordinarius } 217 .\end{array}$ \\
\hline & ns $\left(P I R^{2} \mathrm{I}\right.$ \\
\hline
\end{tabular}

have happened during the reign of Decius. Jacques (1986), 122-123, suggests that they obtained patrician status circa 230.

${ }^{29}$ On Anicius Faustus, consul II 298, and Paulinus, consul ordinarius with Probus 277, see Christol (1986), 114-115; Kreucher (2003), 199; Settipani (2000), 346-348. On the Anicii after the third century, see Jacques (1986), 158-159; Settipani (2000), 432.

${ }^{30}$ PLRE I, Paulinus 16; Settipani (2000), 406-407.

${ }^{31}$ On the Bruttii, see Arnheim (1972), 139-141; Settipani (2000), 340-341 with a stemma. 
Notes

- Probably son of C. Bruttius Praesens, consul ordinarius 217.

- Probably grandfather of Bruttius Praesens $\left(P I R^{2}\right.$ $\mathrm{B}$ 163/PLRE I, Praesens), vir clarissimus late $3 \mathrm{rd} / \mathrm{early}$ 4th century.

The Bruttii, a family from Volcei (Lucania, Italy), can be traced back to the first century $\mathrm{AD}$, but the first consular member of this gens was Bruttius Praesens $\left(P I R^{2} \mathrm{~B} 164\right)$ in the second century. He presumably was the son of an amicus of Plinius and he became consul suffectus under Hadrianus and again as colleague of Antoninus Pius in 139. His son Bruttius Praesens ( $\left.P I R^{2} \mathrm{~B} 165\right)$ also held two consulships: in 153 and 180 . As comes of Marcus Aurelius and Commodus during the expeditio Sarmatica he took part in the Marcomannic wars. This Bruttius Praesens was the father of Bruttius Quintius Crispinus ( $\left.P I R^{2} \mathrm{~B} 169\right)$, consul ordinarius in 187 , and of Bruttia Crispina, who married Commodus in 178. According to Jacques, the gens had reached patrician status by that time. ${ }^{32}$

During the reign of Septimius Severus, no Bruttius is known to have been consul. Strengthening the ties with a family so closely connected with the Antonines would have fit into Severus' dynastic representation policy at the beginning of his reign. ${ }^{33}$ However, Crispina was accused of adultery and exiled to Capri by Commodus, which may explain the absence of the Bruttii in the consular fasti during Severus' reign. Whatever the reason for the absence of the Bruttii was, it was only temporary; three more Bruttii became consul ordinarius during the third century. First came Bruttius Quintius Crispinus' sons Bruttius Praesens in 217 and Bruttius Crispinus in 224. Bruttius Praesens' colleague in 217 was Titus Messius Extricatus ( $\left.P I R^{2} \mathrm{P} 518\right)$, who started his career as eques. ${ }^{34}$ Bruttius Crispinus' colleague in 224 was Appius Claudius Iulianus, who was consul iterum and who had probably been governor of Africa during the reign of Elagabalus or-less likely_Caracalla. Bruttius Praesens

32 On the geographic origins of the Bruttii, see Leunissen (1989), 359; Jacques (1986), 99; Salway (2000), 147, note 161. Plinius addressed Epistula 7, 3 to a (Bruttius) Praesens $\left(P I R^{2}\right.$ B 161). This man was probably the father of Bruttius Praesens, consul II in 139. According to Jacques (1986), 122-123 (cf. 165-166), the gens became patrician under Antoninus Pius.

${ }^{33}$ Mennen (2005), 254-257.

${ }^{34}$ From $A E$ 1977, 171 (Portus, Italy) we know that he was praefectus annonae. Apparently, he was enrolled in the senate afterwards. Salway (1997), 127-153, rejects the usually accepted notion of Cébeillac-Gervasoni (1979) that ... atus from CIL 6.31776a-6 = ILS 1329; CIL 6.31875 (Roma) is to be identified with T. Messius Extricatus. 
was the last member of the gens Bruttia who held a consulate in 246 with Gaius Al[lius] Albinus, whose origin and further career remain unclear. Besides the consulships, no other positions held by these three Bruttii are known to us.

The fact that the third-century Bruttii all served as ordinarii indicates that their high status, which probably resulted mainly from their secondcentury connection with the Antonines, continued until at least the midthird century. A vir clarissimus $\mathrm{Br}(\mathrm{u})$ ttius Praesens $\left(P I R^{2} \mathrm{~B}\right.$ 163/PLRE I, Praesens) mentioned in two inscriptions dated late third or early fourth century presumably descended from Bruttius Praesens, consul ordinarius $246 .^{35}$

Table E4. The Caesonii ${ }^{36}$

\author{
C. Caesonius Macer Rufinianus $\left(P I R^{2} \mathrm{C} 210\right)$ \\ Cursus honorum - Triumvir capitalis \\ - Tribunus militum legionis I Adiutricis ? $178 / 180$ \\ - Quaestor provinciae Narbonensis \\ - Tribunus plebis \\ - Legatus proconsulis Baeticae ca. 185 \\ - Praetor ca. 187 \\ - Legatus proconsulis Asiae \\ - Curator r p Asculanorum \\ - Legatus Aug legionis VII Claudiae ca. 187/190 \\ - Proconsul Achaiae ca. 192 \\ - Curator r p Tarracinensium ca. 193 \\ - Legatus Aug pr pr Lusitaniae?194-?197 \\ - Consul suffectus ca. 197/198 \\ - Curator r p Teanensium ca. 197 \\ - Curator alvei Tiberis ?198/200 \\ - Legatus Aug pr pr Germaniae Superioris ?200-?203 \\ - Curator aquarum et Miniciae?203/213 \\ - Proconsul Africae?213/215 or 218/222? \\ - Curator $r$ p Lanivinorum/Lavininorum II \\ - Comes Aug ?222/235, 231-233?
}

\footnotetext{
35 According to CIL 6.2153 (Roma) and 10.468 (Leucosia, Italy), this man was corrector Lucaniae et Brittiorum and pontifex maior. Both inscriptions read 'Brittius'. It has been suggested in both PIR ${ }^{2} \mathrm{~B} 163$ and PLRE I, Praesens that this $\mathrm{Br}(\mathrm{u})$ ttius Praesens may have been the grandson of Bruttius Praesens, consul 246. Jacques (1986), 99, mentions that the family is still represented at the beginning of the fourth century 'pur senza riacquistare lo splendore precedente.'

${ }^{36}$ See PLRE I, 1137, stemma 11 for a family tree of the Caesonii from the mid-third century onward.
} 
Notes

Notes

Cursus honorum
- Husband of Manilia Lucilla, the sister or daughter of (Ti.) Manilius Fuscus, consul suffectus 196/7, consul II ordinarius 225.

- Father of L. Caesonius Lucillus Macer Rufinianus, consul suffectus?225/230.

L. Caesonius Lucillus Macer Rufinianus ( $P I R^{2} \mathrm{C}$ 209)

Cursus honorum - Decemvir stlitibus iudicandis

- Quaestor candidatus ca. 215/217 or ca. 212?

- Praetor candidatus ca. 220/222, or ca. 217?

- Curator r p Suessanorum

- Curator rp Tuscolanorum/Puteolanorum

- Legatus Africae eodem tempore vice proconsulis ?225/230

- Consul suffectus ?225/230

- Curator alvei Tiberis et cloacarum urbis ?225/230

- Curator aquarum et Miniciae?230/235

- XXvir ex s c r p curandae 238

- Proconsul Africae not before 240/241

- Electus ad cognoscendas vice Caesaris cognitionis $241 / 254,242-244$ ?

- Praefectus urbi 241/254, 246?

- Son of C. Caesonius Macer Rufinianus, consul suffectus ca. $197 / 198$.

- Probably husband of a woman belonging to the gens Ovinia.

- Father of L. Caesonius Ovinius Manlius Rufinianus Bassus, consul suffectus ca. 260, consul II suffectus 284 .

L. Caesonius Ovinius Manlius Rufinianus Bassus (PIR ${ }^{2} \mathrm{C} 212 ; P I R^{2} \mathrm{O}$ 186; PLRE I, Bassus 18)

- Triumvir capitalis after 235?, 240/245?

- Sevir turmae deducendae after 235?, 240/245?

- Quaestor candidatus

- Praetor candidatus

- Curator r p Beneventanorum before 260

- Consul suffectus ca. 260

- Curator alvei Tiberis et cloacarum sacrae urbis

- Legatus proconsulis Africae dioeceseos Carthaginiensis (praetorian?)

- Curator coloniae Carthaginensium (praetorian?)

- Proconsul Africae tertium ca. 275?

- Electus a divo Probo ad praesidendum iudicium magnum ca. $276 / 282$

- Iudex sacrarum cognitionum vice Caesaris sine appellatione cognoscens inter fiscum et privates item inter privates Roma ca. $276 / 281$

- Iudex et in provincia Africa ca. 281/2 
- Comes Augg spring/summer 283?-285

- Praefectus urbi 295

Notes

- Pr[...]ones tracto Piceno

- Son of L. Caesonius Lucillus Macer Rufinianus, consul suffectus ?225/ 230.

- Father or grandfather of Caesonius Bassus, consul ordinarius 317.

- Connected to the Anicii.

A detailed diachronic summary of the political activities of the Caesonii with further references can be found in section 2.2.

Table $\mathrm{E}_{5}$. The Catii

P. Catius Sabinus $\left(P I R^{2}\right.$ C 571)

$\begin{aligned} \text { Cursus honorum } & - \text { Tribunus legionis XIII Geminae in Dacia }{ }^{37} \\ & - \text { Praetor urbanus } \\ & - \text { Legatus Augg pr pr Norici } 206 / 9 \\ & - \text { Consul suffectus } 208 / 10 \\ & - \text { Curator aedium sacrarum operumque publicorum } 210 \\ & - \text { Consul II ordinarius } 216 \text { with P. Cornelius Anullinus } \\ & \text { (consul II) } \\ - & \text { Perhaps identical with the Sabinus whom Elagabalus } \\ & \text { ordered to have killed (HA, Vita Elag. 16, 2-3). } \\ \text { Notes } & \text { Probably ancestor (father or grandfather?) of C. Catius } \\ & \text { Clemens, consul suffectus circa 235, and of L. Catius } \\ & \text { Celer, consul suffectus circa 241. }\end{aligned}$

[Catius? Lepi]dus I[-] (RE Suppl. 14, 88 s.v. Catius 9a)

Cursus honorum - Consul suffectus early 3 rd century?

Notes

- May have been father of Sex. Catius Clementinus Priscillianus, consul ordinarius 230, and of Catius Clemens, consul suffectus circa $235 .{ }^{38}$

\footnotetext{
$37 A E$ 1956, $204=A E$ 2002, 01218 (Dacia).

$38 A E$ 1948, 241 (Dalmatia) attests that this man was consul, (probably) husband of Publicia Quarta, and father of Catia Maximina, C[lementina?], Clementinus, and Clemens. If this Clementinus and Clemens were identical with the consul ordinarius 230, and consul suffectus circa 235, this [Catius? Lepi]dus I[-] probably held his consulship about thirty years before theirs, circa AD 200. On this matter, see RE Suppl. 14, 88, s.v. Catius 9a, and Leunissen (1989), 158f. In my opinion, the possibility that this [Catius? Lepi]dus may have been identical with P. Catius Sabinus should not be excluded.
} 


\begin{tabular}{|c|c|}
\hline \multirow{3}{*}{ Cursus honorum } & Sex. Catius Clementinus Priscillianus $\left(P I R^{2} \mathrm{C} 564\right)$ \\
\hline & - Consul ordinarius 230 with L. Virius Agricola \\
\hline & - Legatus Aug pr pr Germaniae Superioris 231 \\
\hline \multirow[t]{3}{*}{ Notes } & $\begin{array}{l}\text { - May have been a son of [Catius? Lepi]dus I }[-] \text {, consul } \\
\text { suffectus early 3rd century. }\end{array}$ \\
\hline & $\begin{array}{l}\text { - May have been brother of Catius Clemens, consul } \\
\text { suffectus circa } 235 .\end{array}$ \\
\hline & $\begin{array}{l}\text { - May have been brother of L. Catius Celer, consul } \\
\text { suffectus circa } 241 .\end{array}$ \\
\hline \multirow{3}{*}{ Cursus honorum } & C. Catius Clemens (RE Suppl. 14, 88 s.v. Catius 6b) \\
\hline & - Consul suffectus before 238 , ca. 235 \\
\hline & - Legatus Aug pr pr Cappadociae? 236/8 $8^{39}$ \\
\hline \multirow[t]{6}{*}{ Notes } & - Probably descendant (son or grandson?) of P. Catius \\
\hline & Sabinus, consul II ordinarius 216. \\
\hline & - May have been brother of Sex. Catius Clementinus \\
\hline & Priscillianus, consul ordinarius 230. \\
\hline & $\begin{array}{l}\text { - May have been brother of L. Catius Celer, consul } \\
\text { suffectus circa } 241 .\end{array}$ \\
\hline & L. Catius Celer $\left(P I R^{2} \text { A } 1350\right)^{40}$ \\
\hline \multirow[t]{3}{*}{ Cursus honorum } & - Legatus Aug pr pr Thraciae 238/241 \\
\hline & - Consul suffectus (in absentia) ca. 241 \\
\hline & - Legatus Aug pr pr Moesiae Superioris $242^{41}$ \\
\hline Notes & - Probably descendant (son or grandson?) of P. Catius \\
\hline & Sabinus, consul II ordinarius 216 \\
\hline & - Probably related to (brother) Sex. Catius Clementinus \\
\hline & Priscillianus, consul ordinarius 230. \\
\hline & $\begin{array}{l}\text { - May have been brother of C. Catius Clemens, consul } \\
\text { suffectus before } 238 \text {. }\end{array}$ \\
\hline
\end{tabular}

Although the evidence on the Catii is far from clear and scholars have not reached total agreement on their exact family ties, several members of the same branch seem to have held consular positions from the beginning of the third century until the reign of Gordianus III. It has been suggested that Catius Sabinus originated from northern-Italy or Gallia, although an inscription indicates that the Catii owned property in Dalmatia as

\footnotetext{
${ }^{39}$ CIL 3.6924 (Cappadocia). This position was either carried out by him or by his older brother Sex. Catius Clementinus Priscillianus. See Dietz (1980), 354. Eck (1985), 93, note 4, argues that it is more likely that Catius Clemens held it. See also Leunissen (1989), 199, note 308 .

40 His names used to be read erroneously as Q. Atius Celer. That is how he ended up in pars I of $P I R^{2}$. AE 1952, 191 (Moesia Superior), has shown that his name is Lucius Catius Celer. On this, see also RE Suppl. 14, 87, s.v. Catius 6.

${ }^{41}$ See Dietz (190), 120-121.
} 
well. According to Dietz, the third-century Catii descended from Cattius Severus, consul in the second century, and from Catius Marcellus, consul suffectus in 153. Jacques suggests that they may even descend from firstcentury senators. ${ }^{42}$

The first member of the gens to hold a consulship between AD 193 and 284 was Catius Sabinus. He was suffect consul between 208 and 210. He held a second, ordinary, consulate in 216 with Publius Cornelius Anullinus as his colleague. This short interval may indicate that he was a close supporter of Caracalla. In addition to a position as curator between the consulships, no consular positions appear in our evidence for him. ${ }^{43}$

Catius Clementinus Priscillianus was consul ordinarius in 230, before he held a governorship in Germania Superior. He was either Sabinus' son or the son of a [Catius? Lepi]dus I[-], who was consularis and whose name can be deduced from the names of his children, who set up an inscription in honor of him in Dalmatia. ${ }^{44}$ If he was indeed the father of Clementinus and Catius Clemens, consul suffectus circa 235, this [Lepi]dus must have been consul suffectus about AD 200.

Catius Celer was consul suffectus probably under Gordianus III, perhaps during his governorship in Thracia. He held a consular governorship in Moesia Superior in 242. He seems to have been a descendant of Catius Sabinus and related to Clementinus and Clemens, and he was the last member of the gens known to us who held a consulate between 193 and 284 . $^{45}$

Table E6. The Claudii Pompeiani ${ }^{46}$

$\begin{array}{ll} & \text { L. Aurel(1)ius Commodus Pompeianus }\left(P^{2} R^{2} \text { P 568) }\right. \\ \text { Cursus honorum } & - \text { Consul ordinarius } 209 \text { with Q. (Hedius) Lollianus } \\ & \text { Plautius Avitus }\end{array}$

42 On the origin of the Catii, see Alföldy (1968), 137-138. AE 1948, 241 (Dalmatia) points to landed property in that province. On Cattius Severus and Catius Marcellus as ancestors of the third-century Catii, see Dietz (1980), 121-122; 355, who claims that L. Catius Celer descended from these men. On a potential descent from first-century senators, see Jacques (1986), 99.

43 Christol (1986), 31, note 62, suggests that the consul of $208 / 10$ and the consul of 216 may have been two different individuals, who were father and son. For the suggestion that Sabinus was a loyal supporter of Caracalla, see DNP, vol. 2, s.v. Catius [II 6].

44 AE 1948, 241 (Dalmatia).

45 On potential descendants of the third-century Catii in the fourth century, see Jacques (1986), 170.

46 For stemmata see $P I R^{2} \mathrm{P}$ 568, pars 6, 248, no. 26; Dietz (1980), 374, stemma 3; and Settipani (2000), 302. See id., 302, on the difficulties of establishing the relationships between the members of the gens and for further references. 
Notes

Cursus honorum
Notes

Cursus honorum

Notes

Cursus honorum

Notes
- Son of Ti. Claudius Pompeianus (PIR ${ }^{2}$ C 973), consul II ordinarius 173, or of Claudius Pompeianus Quintianus $\left(P I R^{2} \mathrm{C} 975\right)$, quaestorius who died in $182 / 3$ and was son-in-law of Lucilla Augusta. ${ }^{47}$

- May have been father of Claudius Pompeianus, consul ordinarius 231, and of L. Ti. Claudius Aurelius Quintianus (Pompeianus?), consul ordinarius 235.

- Probably uncle of Clodius Pompeianus, consul ordinarius 241.

- May have been the Pompeianus who was executed by Caracalla in $211 / 2 .{ }^{48}$

(Ti. Claudius) Pompeianus $\left(P I R^{2} \mathrm{P} 567 ; 569\right)$

- Consul suffectus 212

- May have been son (or grandson?) of Ti. Claudius Pompeianus, consul II ordinarius $173{ }^{49}$

(Ti.) Claudius Pompeianus $\left(P^{2} R^{2}\right.$ C 972)

- Consul ordinarius 231 with T. Flavius Sallustius Paelignianus

- Son of L. Aurel(l)ius Commodus Pompeianus, consul ordinarius 209, and/or grandson of (Ti. Claudius) Pompeianus, consul suffectus 212. ${ }^{50}$

- Related to (brother of?) L. Ti. Claudius Aurelius Quintianus (Pompeianus?), consul ordinarius 235.

- Related to (brother or cousin of?) Clodius Pompeianus, consul ordinarius 241.

L. Ti. Claudius Aurelius Quintianus (Pompeianus?) (PIR ${ }^{2}$ C 992)

- Triumvir monetalis $221 / 3$

- Quaestor candidatus 228

- Praetor 233

- Consul ordinarius 235 with Cn. Claudius Severus ${ }^{51}$

- Related to (son of?) L. Aurel(1)ius Commodus Pompeianus, consul ordinarius 209.

- Related to (Ti. Claudius) Pompeianus, consul suffectus $212 .^{52}$

47 On Commodus Pompeianus as the son of Ti. Claudius Pompeianus, general of Marcus Aurelius, see Leunissen (1989), 372. On him as the son of Claudius Pompeianus Quintianus, see $P I R^{2} \mathrm{P} 568$. See also Settipani (2000), 301-302.

${ }^{48}$ Herodianus 4, 6, 3; HA, Vita Car., 3, 8; Leunissen (1989), 402. See also Dietz (1983), 389 , with further references.

49 Dietz (1983), 390.

50 See stemma Settipani (2000), 302. Leunissen (1989), 374, assumes he was the son of Aurel(l)ius Commodus Pompeianus, consul ordinarius 209.

${ }^{51}$ These dates are based on Leunissen (1989), 378.

52 According to Leunissen (1989), 374, L. Ti. Claudius Aurelius Quintianus may have 
- Related to (brother or cousin of?) Claudius Pompeianus, consul ordinarius 231.

- Related to (cousin of?) Clodius Pompeianus, consul ordinarius 241.

Cursus honorum

Notes
Clodius Pompeianus ( $P I R^{2}$ C 1177; P 570)

- Quaestor? 234?

- Praetor? 239?

- Consul ordinarius 241 with the emperor Gordianus III

- Curator aedium sacrarum $244^{53}$

- Related to (brother or cousin of?) (Ti.) Claudius Pompeianus, consul ordinarius 231.

The third-century Claudii Pompeiani descended from Ti. Claudius Pompeianus, an important general of Syrian origin under Marcus Aurelius and consul II ordinarius in 173, and Lucilla, Marcus Aurelius' daughter Lucius Verus' widow. ${ }^{54}$ According to the Historia Augusta, Claudius Pompeianus was the son of an eques and thus the first member of this family to enter the senate. ${ }^{55}$ During the reign of Commodus, no member of the gens held a consulship, though Claudius Pompeianus Quintianus, probably the general's nephew and certainly married to the daughter of Lucilla, was quaestor. He was killed in 182 after plotting against Commodus. ${ }^{56}$

Although the exact family ties have been disputed, it is clear that several consular men between $\mathrm{AD} 193$ and 284 belonged to this gens. ${ }^{57}$ First of all, Aurel(1)ius Commodus Pompeianus, who was consul ordinarius in 209, and Pompeianus, suffectus in 212. Unfortunately, nothing is known about their further careers. The next generation flourished under Severus Alexander: Claudius Pompeianus was consul ordinarius in 231 and Claudius Aurelius Quintianus (Pompeianus?) in 235. The fact that

been Ti. Claudius Pompeianus' son. PIR ${ }^{2} \mathrm{P} 567 ; 569$, however, suggests that the consul suffectus of 212 was his uncle.

53 These dates are based on Dietz (1980), 128; 355.

${ }^{54}$ Claudius Pompeianus originated from Antiocheia ad Orontem (Syria). HA, Vita Marc. 20,6: '. .. filiam suam [...] grandaevo equitis Romani filio Claudio Pompeiano dedit genere Antiochensi ...' ('he married his daughter to Claudius Pompeianus, the son of a Roman knight, and now advanced in years, a native of Antioch ...') On his origin, see also Leunissen (1989), 368; Halfmann (1979), 181-182, no. 103; 200-201, no. 135; Bowersock (1982), 664; Dietz (1983), 389 .

${ }^{55}$ HA, Vita Marc. 20, 6.

56 On Quintianus, see Dio 73, 4, 4; Herodianus 1, 8, 4-5.

57 See Settipani (2000), 302, on the difficulties with establishing the exact family ties between the third-century Claudii Pompeiani and for further references. Cf. Dietz (1980), 125 , note 334 . 
the latter was quaestor candidatus indicates that the gens had become patrician by that time. ${ }^{58}$ Clodius Pompeianus, the last known descendant of this consular family, held the consulship in 241.

That the gens Claudia Pompeiana was a significant senatorial family in the third century can be inferred from their influential colleagues. Aurel(l)ius Commodus Pompeianus' colleague in 209 was Lollianus Plautius Avitus, member of the gens Hedia Lolliana. The colleagues of the Pompeiani in 212 and 235 seem to have been members of the gens Claudia Severa, descendants of another general of Marcus Aurelius who was married to another daughter of the emperor. The gens Claudia Pompeiana and the gens Claudia Severa thus both descended from Marcus Aurelius. The colleague of Claudius Pompeianus in 231, Titus Flavius Sallustius Paelignianus, was probably from an Italic patrician family. ${ }^{59}$ Clodius Pompeianus' colleague in 241 was the emperor Gordianus.

There may have been further descendants of this general of Marcus Aurelius, but they did not find their way into the consular fasti. It is striking that family disappears from the sources not long after the end of the Severan dynasty.

Table E7. The Claudii Severi ${ }^{60}$

Ti. Claudius Severus Proculus $\left(P I R^{2} \mathrm{C}\right.$ 1028)

Cursus honorum

Notes

- Consul ordinarius 200 with C. Aufidius Victorinus

- Son of Cn. Claudius Severus $\left(P I R^{2}\right.$ C 1024), consul II ordinarius 173, and of a daughter of Marcus Aurelius.

- Related to (father of?) Cn. Claudius Severus, consul ordinarius 235.

(Cn.? Claudius?) Severus $\left(P I R^{2} S 634\right)$

Cursus honorum

- Consul suffectus 212?

Notes

- Praefectus urbi ?? $223^{61}$

- Related to (son of?) Claudius Severus Proculus, consul ordinarius 200, and to (brother of?) Claudius Severus, consul ordinarius $235 .{ }^{62}$

\footnotetext{
${ }^{58}$ Leunissen (1989), 35, insists that Claudius Aurelius Quintianus was a patricius. Cf. $P I R^{2} \mathrm{C} 992$ Jacques (1986), 122-123, however, does not mention the Claudii Pompeiani among the patrician gentes.

${ }^{59}$ Leunissen (1989), 109 and 360 with further references.

${ }^{60}$ For stemmata, see PIR ${ }^{2}$, vol. I, 130, and Dietz (1980), 374, stemma 3.

${ }^{61}$ Cod. Iust. 4, 56, 2, attests a Severus as praefectus urbi in 223. Leunissen (1989), 176, note 211 , suggests that the city prefect may have been identical with the Severus who was consul suffectus circa 212.

${ }^{62}$ Leunissen (1989), 374, has suggested that he was the father of Cn. Claudius Severus,
} 
Cn. Claudius Severus (PIR ${ }^{2} \mathrm{C}$ 1025)

Cursus honorum - Consul ordinarius 235 with L. Ti. Claudius Aurelius Quintinianus (Pompeianus?)

Notes

- Probably son (or grandson?) of Ti. Claudius Severus Proculus, consul ordinarius $200 .^{63}$

- Brother of Annia Aurelia Faustina, third wife of emperor Elagabalus. ${ }^{64}$

The Claudii Severi descended from Claudius Severus ( $P I R^{2}$ C 1023), a member of the local elite of Pompeiopolis (Galatia) who was admitted into the senate late first or early second century AD and held a suffect consulate in 112. His son Claudius Severus Arabianus was consul ordinarius in 146 and one of Marcus Aurelius' partners in philosophical discussions. ${ }^{65}$ The former fathered Gnaius Claudius Severus, one of Marcus Aurelius' loyal commanders, who married a daughter of the emperor and was consul II ordinarius in 173 with Claudius Pompeianus as his colleague.

The gens Claudia Severa provided three consular men in the first half of the third century: Claudius Severus Proculus in 200, (Claudius) Severus in 212, and Claudius Severus in 235. Claudius Severus Proculus' colleague was Gaius Aufidius Victorinus, who was a member of the Italic gens Aufidia, which was influential in the second half of the second century AD. ${ }^{66}$ The other two shared their consulships with members of the gens Claudia Pompeiana. There are no indications that the Claudii Severi reached patrician status like the Claudii Pompeiani did.

Although the consular fasti mention no member of the Claudii Severi after 235 , the family seemed to have remained members in the senate until at least the reign of Diocletian, when a vir clarissimus called Tiberius Claudius Severus set up a dedication to the emperor. ${ }^{67}$

consul ordinarius 235, but more scholars accept that he was the son of Claudius Severus Proculus and thus brother of Claudius Severus.

${ }^{63}$ Leunissen (1989), 374, suggests that he was the son of (Cn. Claudius) Severus, consul suffectus 212 .

${ }_{64} \operatorname{Dietz}(1980), 128$.

${ }^{65}$ Fronto addressed Ad amicos 1, 1, to him. Birley (1987), 95 f. Cf. HA, Vita Marc. 3, 3 .

${ }^{66} \mathrm{He}$ was the son of C. Aufidius Victorinus, consul II ordinarius in 183, and brother of M. Aufidius Fronto, consul ordinarius 199. The family originated from Pisaurum (Umbria). See Leunissen (1989), 357 and 372.

${ }^{67}$ CIL 6.1119a (Roma), which is dated between 293 and 295. See PIR ${ }^{2} \mathrm{C}$ 1026; PLRE I, Severus 22. 
Table E8. The Egnatii ${ }^{68}$

Cursus honorum

Notes

Cursus honorum

Notes

Cursus honorum
(L.) Egnatius Victor $\left(P I R^{2} \mathrm{E} 35\right)$

- Consul suffectus before 207

- Legatus Augg pr pr Pannoniae Superioris 207

- May have been related to M. Egnatius Postumus (PIR ${ }^{2}$ E 26), consul suffectus $183 .{ }^{69}$

- May have been related to (brother or cousin?) the Egnatii Proculi, consules suffecti late 2nd/early 3rd century. ${ }^{70}$

- Married a sister of Lollianus Plautius Avitus, consul ordinarius 209, and of (Hedius) Terentius Gentianus, consul ordinarius $211 .^{71}$

- Probably father of L. Egnatius Victor Lollianus, consul suffectus ca. 225/230, of (Egnatia) Mariniana, and perhaps also of Egnatius Victor Marinianus, consul suffectus ca. 230. ${ }^{72}$

A. Egnatius Proculus $\left(P I R^{2}\right.$ E 30$)$

- Legatus Aug Africae dioeces(eos) Numidiae

- Legatus legionis VIII Aug. Piae Fidelis in Germania Superior

- Praefectus frumenti dandi

- Praefectus aerarii Saturni

- Consul suffectus late 2 nd/early 3rd century

- Curator Bovianensium, Albensium Fucentium, Concordiensium

- May have been related (brother or cousin?) to Egnatius Victor, consul suffectus before 207.

- Possibly brother of Q. Egnatius Proculus. ${ }^{73}$

Q. Egnatius Proculus $\left(P I R^{2}\right.$ E 29; 31)

- Consul suffectus late 2 nd / early 3 rd century ${ }^{74}$

- Legatus Aug consularis ad corrigendum statum liberarum civitatium provinciae Achaiae

68 Stemmata can be found in Dietz (1980), stemma 7 and Settipani (2000), 398-40o. The exact family ties, however, are disputed.

69 Leunissen (1989), 355 with further references.

70 Dietz (1980), stemma 7. Cf. Settipani (2000), 397-399.

71 Settipani (2000), 406-407.

72 Leunissen (1989), 374; Settipani (2000), 399.

73 According to $P I R^{2}$ E 30 it is unlikely that they were the same man; Chausson has made a suggestion on their relation. See Settipani (2000), 398-399, with further references. However, as far as I can determine, this assumption is not supported by any evidence.

74 According to Settipani (2000), 398-399, he was consul suffectus in 219. 
Notes

Notes
- May have been related (brother or cousin?) to Egnatius Victor, consul suffectus before 207.

- Possibly brother of A. Egnatius Proculus.

- Seems to have been the son-in-law of L. Marius Perpetuus, consul suffectus ca. 203, or of Marius Perpetuus, consul ordinarius $237 .^{75}$

L. Egnatius Victor Lollianus ( $P I R^{2}$ E 36$)$

Cursus honorum

- Legatus Aug pr pr Galatiae $218^{76}$

- Consul suffectus ca. 225/230

- Corrector Achaiae ca. 230

- Legatus Aug pr pr Bithyniae et Ponti 230/235

- Legatus Aug pr pr Pannoniae Inferioris ?? $222 / 235^{77}$

- Proconsul Asiae ter $242 / 247^{78}$

- Praefectus urbi 254

- Probably son of (L.) Egnatius Victor, consul suffectus before 207.

- Probably brother of Egnatius Victor Marinianus, consul suffectus ca. 230, and of (Egnatia) Mariniana Augusta, wife of Valerianus.

- May have been related to Egnatius Lucilianus $\left(P I R^{2}\right.$ E 23), consul suffectus before 238, legatus Augusti pr pr Britanniae (Inferioris) under Gordianus III. ${ }^{79}$

${ }^{75}$ Although it seems likely, it is not entirely certain whether Egnatius Proculus (PIR ${ }^{2}$ E 29), legatus Augusti in Achaia and Q. Egnatius Proculus (PIR ${ }^{2}$ E 31), consul suffectus at an uncertain date, are identical. If not, Q. Egnatius Proculus may have been suffectus later and son-in-law of Marius Perpetuus, ordinarius in 237. This has been suggested by Dietz (1980), 189, and Settipani (2000), 399, who date Proculus' consulate after 260.

76 The dates of all these positions are based on Leunissen (1989), passim.

77 According to Fitz, who based this on very fragmentary remains. Quoted in Leunissen (1989), 210; 257.

${ }^{78}$ Leunissen (1989), 185, suggests that he may have been sent there by Gordianus III extra sortem in connection with the campaign against the Persians and that he was allowed to retain the position under Philippus. Körner (2002), 200, points out that his retention of the office indicates immediate support on his part for Philippus as new emperor.

79 According to Dietz (1980), 357. From CIL 7.445; 1030, we learn that Egnatius Lucilianus was governor of Britannia during the reign of Gordianus. It may be assumed that he previously held a consulship. It has been suggested (see $P I R^{2} \mathrm{E} 23$ ) that this Egnatius Lucilianus may have been the father of Lucillus, consul ordinarius 265 with Gallienus' brother or son Valerianus as his colleague. According to HA, Vita Gall. 12, 1, this Lucillus was related to Gallienus. Jacques (1986), 178-179, however, asserts that a relation between the Egnatii and Egnatius Lucilianus, legatus Britanniae inferioris $238 / 244$ is very doubtful. 


\section{Cursus honorum - Legatus Aug pr pr Arabiae before 230? \\ - Consul suffectus ca. 230 \\ - Legatus Aug pr pr Moesiae Superioris ca. 230?80 \\ Notes \\ - Probably son of (L.) Egnatius Victor, consul suffectus before 207. \\ - Probably brother Egnatius Victor Lollianus, consul suffectus ca. 225/230, and of (Egnatia) Mariniana. ${ }^{81}$ \\ - Brother of L. Egnatius Victor Lollianus, consul suffectus ca. $225 / 230$. \\ - May have been related to C. Luxilius Sabinus Egnatius Proculus (PIR $\left.{ }^{2} \mathrm{~L} 452\right)$, who was tribunus laticlavius legionis IV Flaviae during the reign of Severus Alexander (perhaps under Egnatius Marinianus when he was governor of Moesia Superior)- quaestor pr pr provinciae Cretae Cyrenarum-aedilis Cerialis-praetor-legatus provinciae Achaiae- curator viarum et praefectus alimentorum Clodiae et coherentium-iuridicus regionis Transpadanae-legatus decimae geminae Gordianae 238 / 244-curator rerum publicarum Pisaurensium et Fanestrium. ${ }^{82}$}

Cursus honorum Notes

\section{(Licinius Egnatius) Marinianus (PIR ${ }^{2}$ L 198/PLRE I,} Marinianus 1)

- Consul ordinarius 268 with (Aspasius?) Paternus

- Probably descended from (great-grandson of?) Egnatius Victor Marinianus, consul suffectus ca. 230. Perhaps he was the son of a brother or sister of emperor Gallienus, or the youngest son of Gallienus himself. ${ }^{83}$

- Killed at the end of the reign of Gallienus. ${ }^{84}$

${ }^{80}$ Leunissen (1989), 186 , note 250 , points out that this date, which was suggested by Stein, was based on the assumption that Egnatius (Victor) Marinianus was the father-inlaw of Valerianus. Christol (1986), 191, however, has demonstrated that it is more likely that Egnatia Mariniana was Marinianus' sister. In that case, Marinianus' governorship of Moesia Superior should probably be dated later.

${ }^{81}$ Dietz (1980), 152, follows $P I R^{2}$ E 37 in suggesting that this man was Valerianus' father-in-law. More recently, however, the assumption that Mariniana was a daughter of Egnatius Victor, legatus of Pannonia Superior in 207, instead of a daughter of Egnatius Victor Marinianus, has become the accepted notion. See Christol (1986), 191. Cf. Leunissen (1989), 186, note 250.

82 According to Petersen, PIR ${ }^{2}$ L 452 , followed by Dietz (1980), 183 f., and most recently by Settipani (2000), 397-399. Petersen suggests that this Luxilius Sabinus Egnatius Proculus was related by marriage to the Egnatii Proculi $\left(P I R^{2}\right.$ E 29-33), who had consular careers during the reigns of the Severi.

${ }^{83}$ See PIR L 198; Christol (1986), 109.

${ }^{84}$ Aurelius Victor, Liber de Caesaribus 33, 31; Zonaras 12, 26. 
The Egnatii probably had Etruscan origins, although Bithynian or Numidian origins have also been suggested. ${ }^{85}$ Members of the gens Egnatia first appear in the consular fasti late second, early third century AD.

Egnatius Victor held a consulate in 207. Egnatius Victor Lollianus, consul suffectus ca. 225 / 230, and Egnatius Victor Marinianus, consul suffectus ca. 230, were probably his sons, and presumably he had a daughter (Egnatia) Mariniana, who would marry the future emperor Licinius Valerianus. Valerianus, who seems to have been a supporter of the Gordiani, might have convinced his brother-in-law Egnatius Victor Lollianus to support them as well. In any case, it is striking that the summit of Lollianus' career was reached at the end of the reign of Gordianus III, when he held the position of governor of Africa for three years. That members of the gens Egnatia continued to hold consular positions during the reigns of Valerianus and Gallienus is of course not surprising. Egnatius Victor Lollianus was city prefect in 254, and Marinianus was consul ordinarius in 268 with a colleague named Paternus, whose identity cannot be determined. That no member of the gens Egnatia held consular positions in the period 268 to 284 is even less surprising, as the family was related to Gallienus. Most members of the gens were probably killed with the emperor, or at least lost their wealth and status.

The Egnatii were connected to the Hedii Lolliani through marriage. It has also been suggested that the Egnatii Victores were related to the Egnatii Proculi, who underwent consular careers under the Severi and were related through marriage to the Marii. ${ }^{86}$ In the fourth century, the Egnatii appear in the consular fasti again, by which time they may have established relations with the Acilii as well. ${ }^{87}$

85 On their origins, see Dietz (1980), 356; Jacques (1986), 178; Leunissen (1989), 358 and 360 ; Körner (2002), 191 and 338.

${ }^{86}$ Based on an unpublished inscription, Jacques (1986), 178-179, suggests relations between Valerianus and Egnatius Certus Settianus, who was attested in Beneventum in 254 (RE Suppl. 14, 115, no. 17a). This Egnatius was probably the son of C. Egnatius Certus $\left(P I R^{2} \mathrm{E} 20\right)$, consul suffectus in the first half of the third century. According to Jacques, however, these Egnatii Certi probably belonged to a separate but related branch of Egnatii from Beneventum.

87 According to Jacques (1986), 178-179. 
Table E9. The Fulvii Aemiliani

\begin{tabular}{|c|c|}
\hline & Fulvius Gavius (Numisius) Petronius Aemilianus \\
\hline Cursus honorum & $\begin{array}{l}\text { - Consul ordinarius } 206 \text { with M. Nummius Umbrius } \\
\text { Primus Senecio Albinus }\end{array}$ \\
\hline \multirow[t]{2}{*}{ Notes } & $\begin{array}{l}\text { - Perhaps father of Fulvius Aemilianus, consul ordinarin } \\
\text { 244, and of Fulvius Aemilianus, consul II ordinarius } \\
249 .{ }^{88}\end{array}$ \\
\hline & $\begin{array}{l}\text { L. Fulvius Gavius N[umisius ... ] Aemilianus }\left(P I R^{2}\right. \\
\text { F 540) }\end{array}$ \\
\hline \multirow[t]{4}{*}{ Cursus honorum } & $\begin{array}{l}\text { - (Quaestor candidatus?) } \\
\text { - Praetor candidatus }\end{array}$ \\
\hline & \\
\hline & - Consul suffectus $223 / 235 ; 226$ or $229 ?^{89}$ \\
\hline & $\begin{array}{l}\text { - Consul II ordinarius ?? } 249^{90} \\
\text { - Praefectus urbi ?? } 249^{91}\end{array}$ \\
\hline \multirow[t]{2}{*}{ Notes } & $\begin{array}{l}\text { - Perhaps son of Fulvius Aemilianus, consul ordinarius } \\
206 \text {. } \\
\text { - Perhaps older brother of Fulvius Aemilianus, consul } \\
\text { ordinarius } 244 \text {. }\end{array}$ \\
\hline & L. Fulvius Gavius Numisius Aemilianus $\left(P I R^{2} \mathrm{~F} 529\right)$ \\
\hline Cursus honorum & $\begin{array}{l}\text { - Quaestor } 237 \\
\text { - Consul ordinarius } 244 \text { with Ti. Pollenius Armenius } \\
\text { Peregrinus }\end{array}$ \\
\hline Notes & - Perhaps son of F. Gavius (Numisius) Petronius \\
\hline & Aemilianus, consul ordinarius 206. \\
\hline & $\begin{array}{l}\text { - Perhaps brother of F. Fulvius Gavius N[umius] } \\
\text { Aemilianus, consul suffectus } 222 / 235 \text {. }\end{array}$ \\
\hline
\end{tabular}

It is hard to determine when the Fulvii Aemiliani, who seem to have had been of Italian origin, entered the senate. ${ }^{92}$ Lucius Fulvius Rusticus Aemilianus (PIR $\left.R^{2} \mathrm{~F} 557\right)$ was consul suffectus in the second century and probably the father of Lucius Fulvius Gavius Numisius Petronius

\footnotetext{
88 Leunissen (1989), 374; Körner (2002), 338.

89 The date is based on Leunissen (1989), 187-188.

90 It is possible that it was his younger brother Fulvius Aemilianus, consul ordinarius 244 , who held this second consulship in 249 , but that would leave a very short interval between the two consulates. That is why nowadays it is assumed that this consulship was held by this Fulvius Aemilianus, who had been suffectus under Severus Alexander. See Leunissen (1989), 187, note 257 for further references.

91 See Dietz (1980), 165, with further references.

92 On their origins, see Dietz (1980), 356; Leunissen (1989), 358; 360; Körner (2002), 338.
} 
Aemilianus (PIR $\left.{ }^{2} \mathrm{~F} 541\right)$ who was quaestor candidatus and not much later praetor tutelarius candidatus, probably in 169, appointed by Marcus Aurelius and Lucius Verus. By that time, the family seems to have had patrician status. ${ }^{93}$

The first consular member between AD 193 and 284 was Fulvius Gavius (Numisius) Petronius Aemilianus who was consul ordinarius in 206. He was probably the son of the praetor tutelarius of 169 and seems to have been the father of the Fulvius Aemilianus, consul suffectus under Severus Alexander and consul iterum in 249, and of Fulvius Aemilianus, consul ordinarius in $244 .{ }^{94}$ Their consular colleagues were all successful senators: the other consul ordinarius in 206 was Marcus Nummius Umbrius Primus Senecio Albinus, member of the patrician gens Nummia, which will be discussed below. In 244, the second consul ordinarius was Tiberius Pollenius Armenius Peregrinus who was adopted into the gens Polliena, and then in 249, Lucius Naevius Aquilinus, who would hold the position of governor of Africa under Gallienus, became Fulvius Aemilianus' colleague.

It has been suggested that the gens Fulvia Aemiliana had been related to the Bruttii since the first century $\mathrm{AD}$ and that the gens also had connections with the Nummii Umbrii. ${ }^{95}$ Laelius (Fulvius?) Maximus Aemilianus, consul ordinarius in 227 , may have been distantly related as well. ${ }^{96}$ After 249, no member of the gens Fulvia Aemiliana can be traced in the consular fasti, although it has been suggested that Aemilianus, consul II ordinarius in 276 , belonged to this gens. ${ }^{97}$ Yet such a connection cannot be established with certainty.

${ }^{93}$ On their patrician status, see Dietz (1980), 160; Leunissen (1989), 35; Körner (2002), 338. Jacques (1986), 122-123, does not include the Fulvii in his list of patrician families.

94 The city prefect Fulvius mentioned by Dio 80, 21, 1-2, who was killed in 222 immediately after the death of Elagabalus, may also have been related to this gens, but there are other possibilities. Leunissen (1989) 166, note 167, for example, assumes that the city prefect was identical to C. Fulvius Maximus, consul suffectus before 210.

95 On this matter, see Dietz (1980), 161-163, with further references. The posited connection with the Bruttii is based on the nomenclature of L. Fulvius ... C. Bruttius Praesens (PIR B 165), consul 153, consul II ordinarius 180.

${ }^{96}$ According to Settipani (2000), 152, Laelius (Fulvius?) Maximus Aemilianus was the grandson of a sister of Fulvius Gavius Aemilianus, praetor 169. Alföldy (1982), 363, also mentions close ties ('enge Beziehungen') between the Laelii Maximi and the Fulvii.

97 See Dietz (1980), 368, stemma 4. 
Table E10. The Hedii Lolliani ${ }^{98}$

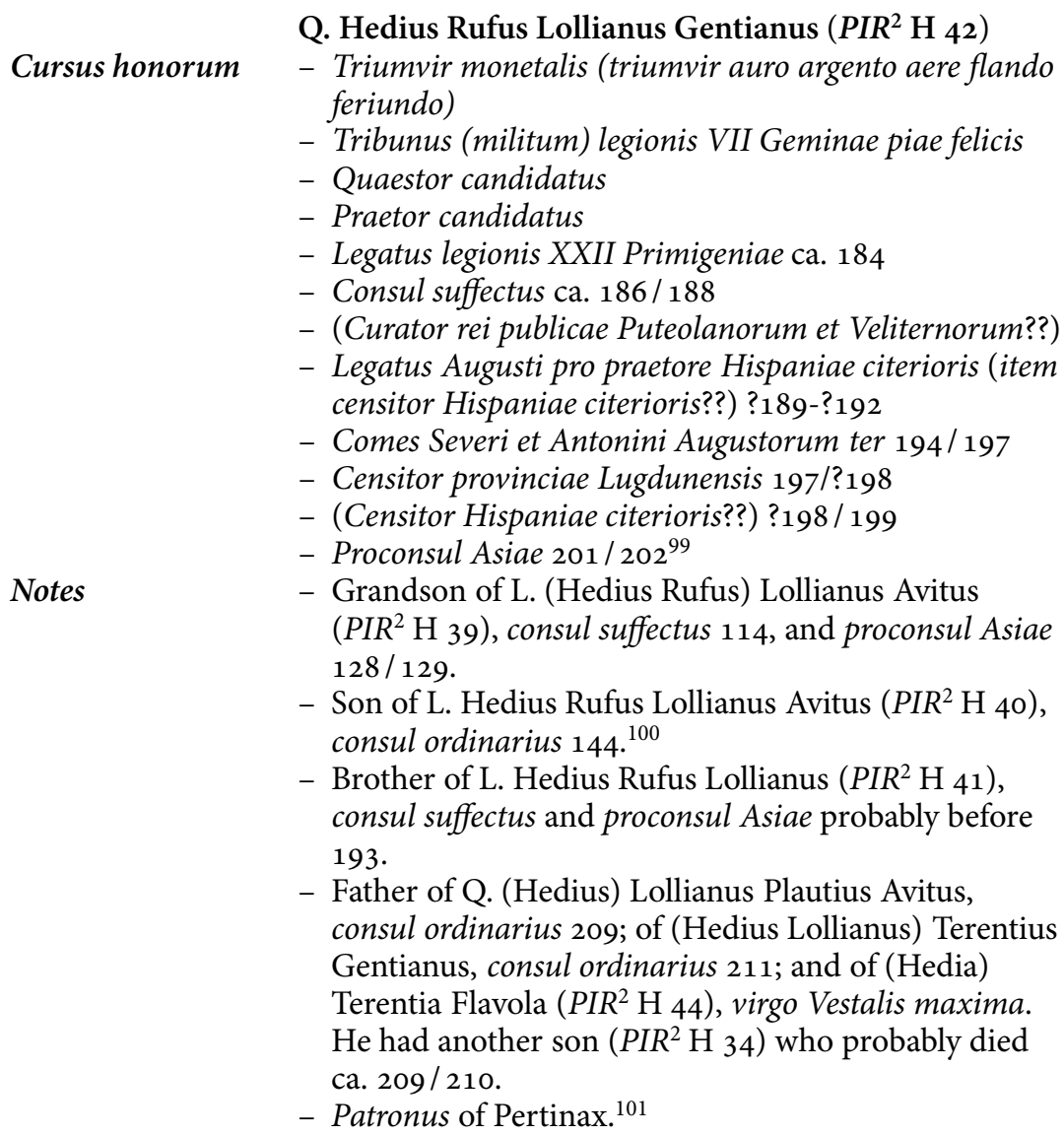

98 A stemma is in $P^{2}{ }^{2}$, pars IV, fasc. 2, 52 and Settipani (2000), 407. On (members of) the family, see also Christol (1981); Alföldy (1982), 326 no. 5; Guidanti (1995).

99 These dates are based on Christol (1981).

${ }^{100}$ L. Hedius Rufus Lollianus Avitus was consul ordinarius in 144, curator operum publicorum 146, proconsul Africae probably 157/158, legatus Augg pro praetore Bithyniae (et Ponti) 159. He was probably assigned a special task when Verus left the East. Furthermore, he was an orator, amicus of Fronto, and patronus of Helvius Successus, Pertinax' father. He was married to a daughter of Terentius Gentianus, consul suffectus 116.

101 According to $P I R^{2} \mathrm{H}$ 42, basing this on the fact that his father was Pertinax' father's patronus. 
Q. (Hedius) Lollianus Plautius Avitus $\left(P I R^{2} \mathrm{H}_{36}\right.$ )

Cursus honorum

- Triumvir monetalis auro argento aere flando feriundo

- Tribunus laticlavius legionis XIII Geminae in Dacia

- Quaestor candidatus 195 ?

- Praetor candidatus tutelaris 200

- Legatus Augg provinciae Asiae 201/ 202

- Iuridicus Asturiae et Callaeciae

- Legatus legionis VII Geminae piae fidelis in Hispania Citerior 202-?205

- Consul ordinarius 209 with Aurel(1)ius Commodus Pompeianus

Notes

- Proconsul Asiae ca. 224? ${ }^{102}$

- Son of Q. Hedius Rufus Lollianus Gentianus, consul suffectus ca. 186/ 188.

- Brother of (Hedius Lollianus) Terentius Gentianus, consul ordinarius 211.

Cursus honorum

Notes
(Hedius Lollianus) Terentius Gentianus $\left(P^{2} R^{2} \mathrm{H}_{37}\right)$

- Praetor tutelaris 209

- Consul ordinarius 211 with (Pomponius) Bassus

- Son of Q. Hedius Rufus Lollianus Gentianus, consul suffectus ca. 186/ 188.

- Brother of Q. (Hedius) Lollianus Plautius Avitus, consul ordinarius 209.

- Married to Pomponia Paetina, who seems to have been related to (Pomponius) Bassus, Terentius' consular colleague in $211 .{ }^{103}$

The gens Hedia Lolliana, which was probably from Liguria (Italy), occurs as consular family during the second century and the beginning of the third century AD. ${ }^{104}$ The third-century Hedii Lolliani were descendants of Lucius (Hedius) Lollianus Avitus, consul suffectus in AD 114. His son, Lucius Hedius Rufus Lollianus Avitus, was consul ordinarius exactly thirty years later: AD 144. It was probably this man, who dared criticize Pertinax for breaking a promise, according to the Historia Augusta. ${ }^{105}$ Even if the incident was made up, the suggestion that a Lollianus could do this demonstrates that the gens was powerful at the end of the second century AD.

\footnotetext{
102 The dates are based on Leunissen (1989), passim.

103 According to $P I R^{2} \mathrm{H} 37$ and $\mathrm{P} 707$, the name of C. Pomponius Bassus Terentianus, consul suffectus circa 193, appears to indicate that the gentes were united at the end of the second century AD.

104 The gens had properties in Liguria, where Pertinax was born as well. On the geographical origin of the gens, see Leunissen (1989), 356.

${ }^{105}$ HA, Vita Pert. 7, 6.
} 
Between AD 193 and 284 consular positions were held by several members of the gens. First of all, Hedius Rufus Lollianus Gentianus, who was consul suffectus circa 186/188. He joined the emperor's entourage thrice during the early years of the reign of Septimius Severus, after which he held several positions as censitor and eventually became governor of Asia. ${ }^{106}$ Considering the fact that he was both quaestor and praetor as imperial candidatus, the gens must have reached patrician status by that time. Gentianus' older brother, Lucius Hedius Rufus Lollianus $\left(P I R^{2}\right.$ $\mathrm{H} 41$ ), was consul suffectus and proconsul Asiae as well, but he may have held these positions before 193 and there is no evidence that his career continued during the reign of Severus. Lollianus Plautius Avitus, son of Gentianus, held an ordinary consulship at the end of the reign of Severus and, like his father, was proconsul Asiae, probably shortly after Severus Alexander became emperor. His colleague, Aurel(l)ius Commodus Pompeianus, was a member of the gens Claudia Pompeiana, and his brother, Terentius Gentianus, was consul ordinarius in 211 with (Pomponius) Bassus as his colleague, who may have been a relative. ${ }^{107}$

The sister of the consuls of 209 and 211 married Egnatius Victor. Their daughter, (Egnatia) Mariniana, would marry the future emperor Valerianus, while their son, Lucius Egnatius Victor Lollianus, held a suffect consulship in 225 and seems to have been the last consul bearing the name Lollianus. ${ }^{108}$

${ }^{106}$ He can only have been comes thrice at the beginning of Septimius Severus' reign, in the expedition against Niger (expeditio Asiana), the first Parthian War, and against Albinus (expeditio Gallica). Birley (1988), 76, suggests that Septimius Severus and Lollianus Gentianus may have met when Severus was governor of Lugdunensis and Lollianus Gentianus was on his way from Rome to Moguntiacum to take up his position as commander of legion XXII Primigenia. There is no evidence that they actually met then and there, but it is very unlikely that Septimius Severus did not know him, or at least his father, who was one of the more senior senators in those days.

107 (Pomponius) Bassus, the consul ordinarius in 211, may have been the son of [C. Pomponius] Bass[us Terentianus], consul suffectus circa 193, but since their names were not preserved completely, this is hypothetical. For this suggestion and further references, see Leunissen (1989), 357, note 26.

108 Two more male Hedii Lolliani of next generations are known to us: (Q. Hedius) Lollianus Gentianus, probably a nephew of (Hedius) Terentius Gentianus, consul ordinarius 211, and Q. (Hedius) Terentius Rufus. Although apparently they were senators, since they were called vir clarissimus, they do not appear in the consular fasti. 
Table E11. The Marii ${ }^{109}$

\begin{tabular}{|c|c|}
\hline & L. Marius Maximus Perpetuus Aurelianus $\left(P I R^{2}\right.$ \\
\hline \multirow[t]{21}{*}{ Cursus honorum } & - Quattuorvir viarum curandarum under Marcus \\
\hline & - Tribunus laticlavius legionis XXII Primigeniae \\
\hline & - Tribunus laticlavius legionis III Italicae 178/180 \\
\hline & - Quaestor urbanus ?182/183 \\
\hline & - Tribunus plebis candidatus \\
\hline & - Adlectus inter praetorios \\
\hline & - Curator viae Latinae ca. 190 \\
\hline & - Curator rei publicae Faventinorum N-Italy \\
\hline & - Legatus legionis I Italicae ca. 193 \\
\hline & $\begin{array}{l}\text { - Dux exercitus Mysiaci (= Moesiaci) apud Byzantium } \\
193 / 196\end{array}$ \\
\hline & - Dux exercitus Mysiaci apud Lugdunum 197 \\
\hline & - Legatus Augustorum pro praetore Belgicae 197-?199 \\
\hline & - Consul suffectus ca. $199 / 200^{111}$ \\
\hline & - Legatus Augusti pr pr Germaniae Inferioris \\
\hline & - Legatus Augg pr pr Syriae Coelis ?205-?208 \\
\hline & - Proconsul Africae ?213/214 or ?216/217 \\
\hline & - Proconsul Asiae II $214-216$ or $213^{-215^{112}}$ \\
\hline & - Praefectus urbi 218-219 \\
\hline & - Consul II ordinarius 223 with L. Roscius Aelianus \\
\hline & Paculus Salvius Iulianus \\
\hline & - (Curator Ardeatinorum??) \\
\hline Notes & - Son of equestrian procurator L. Marius Perpetuus $\left(P I R^{2}\right.$ \\
\hline & $\left.\mathrm{M}_{313}\right)^{113}$ \\
\hline & $\begin{array}{l}\text { - Brother of L. Marius Perpetuus, consul suffectus } \\
\text { ca. 203? }\end{array}$ \\
\hline & - Father of L. Marius Maximus, consul ordinarius 232. \\
\hline
\end{tabular}

109 Stemmata can be found in $P I R^{2}$, pars V, fasc. 2, 205; Dietz (1980), stemma 7; Settipani (2000), 399.

${ }^{110}$ His career is rendered completely in CIL 6.1450 = ILS 2935 (Roma). On his career, see also Birley (1997b), esp. 2694-2703. The dates are based on Leunissen (1989), 382.

111 Probably during his service as governor of Belgica. See Leunissen (1989), 284.

112 Both that he held this position for two consecutive years and that he was both proconsul Africae and proconsul Asiae were highly unusual. On this, see Leunissen (1989), 217 and 224-225. See Thomasson (1996), 85 about the problem of dating and deciding which proconsulship was first.

113 Leunissen (1989), 48. L. Marius Perpetuus was procurator monetae, procurator vicesimae hereditatium, procurator stationis hereditatium and procurator provinciae Lugdunensis et Aquitaniae. He was a protégé of Gavius Maximus, praefectus praetorio under Antoninus Pius. 


\section{Cursus honorum}

Notes

Cursus honorum Notes
- Related to (father/uncle of?) L. Marius Perpetuus, consul ordinarius 237.

- Author of the lives of emperors from Nerva until Elagabalus. ${ }^{114}$

L. Marius Perpetuus $\left(P I R^{2} M_{311}\right)$

- $(\text { Vigintivir? })^{115}$

- Tribunus laticlavius legionis IV Scythicae in Syria

- Quaestor candidatus Augusti

- (Tribunus plebis/aedilis?)

- (Praetor?)

- (Adlectio inter praetorios?)

- Legatus legionis XVI Flaviae firmae in Syria Coele under governor Alfenus Senecio 200 or ca. 203

- Legatus (praeses) Augg pr pr Arabiae ca. 200/207

- Consul suffectus ca. 203? or 208? or 214?

- Curator rerum publicarum Urbisalviensium (in Piceno) item Tusculanorum 204/211? ${ }^{116}$

- Legatus Aug pr pr Moesiae Superioris 211-214?, or 208-211?

- Legatus Aug pr pr Tres Daciae 214?-215/216, or 211-214 (the latter according to PIR) ${ }^{117}$

- Proconsul (Africae/Asiae??) ca. 218/219? ${ }^{118}$

- Son of equestrian procurator L. Marius Perpetuus $\left(P I R^{2}\right.$ M 313).

- Brother of L. Marius Maximus Perpetuus Aurelianus, consul II ordinarius 223.

- Uncle of L. Marius Maximus, consul ordinarius 232.

- Related to (father/uncle of?) L. Marius Perpetuus, consul ordinarius 237.

L. Marius Maximus (PIR ${ }^{2}$ 307)

- Consul ordinarius 232 with Virius Lupus (Iulianus?)

- Son of L. Marius Maximus Perpetuus Aurelianus, consul II ordinarius 223.

- Brother or cousin of L. Marius Perpetuus, consul ordinarius 237.

\footnotetext{
114 HA, Vita Elag. 11,6.

115 The dates of many positions are disputed. Those mentioned here are based mainly on Leunissen (1989), 379, and Thomasson (1985), 125-126. Cf. PIR ${ }^{2}$ M 312.

116 According to $P I R^{2} \mathrm{M} 312$, the consulship was held after his curatorships in Italy.

117 CIL $3.1178=$ ILS 1165 (Dacia) points at judicial duties in Dacia ("praeses iustissimus').

118 Based on CIL 6.41188 = AE 1987, no. 69 (Roma). See Leunissen (1989), 228.
} 


\section{Marius Perpetuus $\left(P I R^{2} M_{312}\right)$ \\ Cursus honorum - Consul ordinarius 237 with L. Mummius Felix Cornelianus \\ Notes \\ - Son or nephew of L. Marius Maximus Perpetuus Aurelianus, consul II ordinarius 223. \\ - Son or nephew of L. Marius Perpetuus, consul suffectus ca. 203? \\ - Brother or cousin of L. Marius Maximus, consul ordinarius 232. \\ - Perhaps brother-in-law of Egnatius Proculus, consul suffectus late 2 nd/early 3 rd century. ${ }^{119}$}

The gens Maria probably had its origins either in Italy or in Africa. ${ }^{120}$ In the second century the family had equestrian status. Apparently, procurator Marius Perpetuus secured entry into the senatorial order for his sons.

At the beginning of the reign of Septimius Severus, Marius Maximus, probably the elder son, was able to extend the status of the family due to loyal service as $d u x$ of the new emperor during the civil wars. The gens having become part of the high nobility. General Marius Maximus was rewarded with a suffect consulate soon after the wars, circa 199/200. His brother Marius Perpetuus was also appointed consul suffectus, although it has been disputed whether his consulship was held under Severus, soon after his brother's, or under Caracalla. While most of the consular part of Perpetuus' career seems to have taken place under Severus' son, Marius Maximus' consular career covered the reigns of all the Severi, up to the beginning of the reign of Severus Alexander. That Marius Maximus was made proconsul of both Africa and Asia under Caracalla, and that he even served a double term in the latter, was unprecedented, and suggests that the emperor held him in high regard. Apparently, this did not prevent Caracalla's successor Macrinus from appointing him city prefect in 218, as successor of Oclatinius Adventus. During the reign of Elagabalus, Marius Maximus disappeared from public view, but he reappeared as consul iterum as colleague of Lucius Roscius Aelianus Paculus Salvius Iulianus, the son of Roscius Aelianus Paculus, consul ordinarius in 187, and the stepson of Marcus Nummius Umbrius Primus Senecio Albinus, consul ordinarius in $206 .{ }^{121}$

Another Marius Maximus, probably the son of the consul iterum of 223, held an ordinary consulate in 232 with Virius Lupus (Iulianus?) as

119 See Dietz (1980), stemma 7.

120 On their origins, see Dietz (1980), 358; Leunissen (1989), 362-364.

${ }^{121}$ Leunissen (1989), 373. 
his colleague, a member of the gens Viria. Marius Perpetuus, another member of this gens, was consul ordinarius in 237 under Maximinus Thrax. His colleague, Lucius Mummius Felix Cornelianus, seems to have been related to the patrician Lucius Mummius Maxi[mus] Fa[us]tinianus, and to Mummius Bassus, consul ordinarius in 258. ${ }^{122}$ Unfortunately, nothing is known about the further careers of these last two Marii.

After 237, the gens seems to have disappeared completely from the consular fasti. The Marii were connected to the Egnatii (Proculi) through marriage. ${ }^{123}$

Table E12. The Nummii ${ }^{124}$

M. Nummius Umbrius Primus Senecio Albinus $\left(P I R^{2}\right.$

$\mathrm{N} 238$ )

Cursus honorum - Triumvir monetalis (auro argento aere flando feriundo $^{125}$

- Sevir equitum Romanorum turmae primae

- Curator Cart(aginensium)

- Quaestor candidatus Augg ca. 199

- Legatus (proconsulis) Asiae and/or Africae? ca. 202, or 208/ 209 ? 126

- Praetor candidatus Augg ca. 204

- Consul ordinarius 206 with Fulvius Aemilianus

- Electus ab Augustis ad cognoscendum vice sacra 208/209?

- Legatus Augg/Aug pr pr Hispaniae Citerioris 209?/211212 ?

- Legatus Augg pr pr Dalmatiae 212?-214?

- Proconsul Asiae?? ca. 221/222 127

122 Dietz (1980), 191.

${ }_{123}$ Maria Aurelia(na) Violentilla ( $\left.P I R^{2} \mathrm{M} 325\right)$, probably daughter of Perpetuus, consul ordinarius 237, married Q. Egnatius Proculus $\left(P I R^{2} \mathrm{E} 31\right)$, consul suffectus at an uncertain date. See Dietz (1980), 189; Settipani (2000), 399.

${ }^{124}$ For stemmata, see PLRE I, 1142, no. 21 and Settipani (2000-2002), addenda I, 26; 34-35. According to Jacques (1986), 200, responsibility for the obscurity of this gens lies in the Historia Augusta which created anachronistic relations between the Ceionii and the Nummii to praise them.

${ }^{125}$ Much discussion has focused on the exact course of this man's career. In addition to $P I R^{2}$ N 238, see also Leunissen (1989), 226; 240; Peachin (1996), 97-100 for some more recent views on, for instance, dates of positions and with further references.

126 Thomasson (1996), 115, no. 51, argues that Nummius Albinus was legatus in both Africa and Asia.

127 Suggested by Eck in RE Suppl. 14, $288 \mathrm{ff}$. 
Notes

Cursus honorum

Notes

Cursus honorum

Notes
- Probably the son of Nummius Albinus ( $P I R^{2}$ N 226), (half-)brother of Didius Iulianus, and adopted son of M. Umbrius Primus (PIR V 596), proconsul Africae ca. $201 / 202 .^{128}$

- Father of M. Nummius Senecio Albinus, consul ordinarius 227.

M. Nummius Senecio Albinus (PIR ${ }^{2}$ N 235)

- Consul ordinarius 227 with Laelius (Fulvius?) Maximus Aemilianus

- Son of M. Nummius Umbrius Primus Senecio Albinus, consul ordinarius 206.

- Stepbrother (frater uterinus) of L. Roscius Aelianus Paculus Salvius Iulianus, consul ordinarius 223. ${ }^{129}$

- Father of M. Nummius Tuscus, consul ordinarius 258, and perhaps also of M. Nummius Albinus, consul II ordinarius 263.

M. Nummius Albinus (= M. Nummius Attidius Senecio Albinus) $\left(P I R^{2} \mathrm{~N} 227 / P L R E \text { I, Albinus 9 }\right)^{130}$

- (Consul suffectus before 256, ca. 240?)

- Praefectus urbi 256 and 261-263

- Consul II ordinarius 263 with Dexter/Maximus

- Perhaps son of M. Nummius Senecio Albinus, consul ordinarius $227 .{ }^{131}$

128 That Senecio Albinus' father was a brother of Didius Iulianus, is recorded in the Historia Augusta, Vita Did. Iul., 1, 1-2. There is some question as to whether Nummius Umbrius Primus Senecio Albinus was the son of Nummius Albinus and then adopted by M. Umbrius Primus, the traditional view, or whether he was the son of Umbrius Primus and adopted by Nummius Albinus. Cf. PIR V 3; Leunissen (1989), 109; Peachin (1996), 98 , note 34. Contrary to what has been suggested, Nummius Albinus $\left(P I R^{2} \mathrm{~N} 226\right)$ was not identical to Ceionius Albinus ( $P I R^{2}$ C 599), who was killed by Septimius Severus, since it has become clear that the Nummii and Ceioni were not linked before the end of the third century AD.

129 Settipani (2000-2002), addenda I, 36, suggests that Roscius Aelianus Paculus Salvius Iulianus was more distantly related to Nummius Senecio Albinus, consul ordinarius 227.

${ }^{130} C I L$ 06.41225a $=A E$ 2000, $93=A E$ 2000, 179 (Roma). [Nu]mmius Albi[nus] $\left(P I R^{2}\right.$ $\mathrm{N} 228$ ) may have been identical with this man. He was either praeses or legatus proconsulis in Lycia et Pamphylia, or he at least owned property there. Nummius Albinus (PIR ${ }^{2}$ $\mathrm{N}$ 229), who dedicated an altar to Iuppiter Serenus in Rome (CIL 6.433 = ILS 3042, Roma), was also a member of the gens Nummia Albinia, but it is uncertain whether he is identical with one of the other Nummii Albini. The same goes for M. Nummius Albinus (PIR ${ }^{2} \mathrm{~N} 230$ ), who is mentioned on the epitaph of a female slave (CIL 9.4330, Aquila, Italy). By now it has become clear that Nummius Aemilianus Dexter flourished at the end of the fourth century AD. See PLRE I, Dexter 1, with further references. Nevertheless, Thomasson (1972-1990), vol. I, 27, no. 195, still assumes that he is identical with Aemilianus, consul in 259.

${ }^{131}$ Christol (1986), 215-216, thinks not, because of the age difference. Jacques (1986), 
Cursus honorum Notes
- Perhaps brother of M. Nummius Tuscus, consul ordinarius 258.

- Probably the member of the gens who died of old age under Aurelianus. ${ }^{132}$

M. Nummius Tuscus $\left(P I R^{2} \mathrm{~N} 237\right)$

- Consul ordinarius 258 with Mummius Bassus

- Son of M. Nummius Senecio Albinus, consul ordinarius 227.

- Perhaps brother of M. Nummius Albinus, consul II ordinarius 263.

- Probably father of M. Nummius Tuscus ( $P I R^{2} N$ 236), consul ordinarius $295 .{ }^{133}$

- According to SHA, Aurel. 13, 1, he visited public baths in Byzantium with emperor Valerianus, praefectus praetorio Baebius Macer, and some other people.

The origin of Nummius Umbrius Primus Senecio Albinus is unclear: the family seems to have had property in Brixia (N-Italy) which indicates that Nummius Albinus may have been born there, but he may also have originated from Beneventum (S-Italy, Campania), a city of which he was patronus. The fact that the Umbrii Primi from Compsa, the family which had adopted Nummius Albinus, had close connections with the city of Beneventum strengthens the presumption that Nummius Albinus had his origins there. Either way, it is likely that he had Italic roots or was at least strongly connected to cities in Italy.

Senecio Albinus seems to have been the first member of the gens to hold a consulship in 206. His colleague was Fulvius Aemilianus, of the gens Fulvia Aemiliana. Umbrius Primus, who was probably Senecio Albinus' adoptive father, had been consul suffectus ca. 185/186 and was proconsul of Africa only a few years before his adopted son's consulship. ${ }^{134}$ Since our Senecio Albinus started his career as triumvir monetalis and he was both quaestor and praetor as candidatus Augusti, he seems to have had patrician status, which is quite surprising if he was indeed

201, suggests that he was the son of Nummius Umbrius Primus Senecio Albinus, consul ordinarius 206.

132 Petrus Patricius, Continuator Dio, Excerpta de Sententiis 174.

133 This Nummius Tuscus ( $\left.P I R^{2} \mathrm{~N} 236\right)$ was consul ordinarius in 295 with C. Annius Anullinus (PIR A 632) as his colleague. After 295, he was curator aquarum et [Miniciae], and praefectus urbi 302/303. See CIL 6.31378b = ILS 643 (Roma).

${ }^{134}$ Leunissen (1989), 215-216, dates the proconsulship at ca. 201/202; Settipani (2000), 385, dates it at 204. It has been suggested that Senecio Albinus was quaestorian legatus in Africa when his father was governor of this province. On this, see Peachin (1996), 98-100, with further references. 
related to Severus' former rival Didius Iulianus and if his father was indeed condemned to death by Severus in $193 .{ }^{135} \mathrm{He}$ was even entrusted with a position cognoscens vice sacra, judging as deputy of the emperors, perhaps in 208 when Severus and his sons left the capital. ${ }^{136}$

The next member of the Nummii with a consular career was Nummius Senecio Albinus, consul ordinarius in 227. He was Senecio Albinus' son and his consular colleague was Laelius (Fulvius?) Maximus Aemilianus, of whom it has been suggested that he was distantly related to the senatorial gens Fulvia. ${ }^{137}$

Nummius Albinus was praefectus urbi in 256 and again from 261 to 263, and consul iterum in 263. ${ }^{138}$ He was perhaps a son of the consul of 227, just like Nummius Tuscus, consul ordinarius in 258, who-if we may believe the Historia Augusta-visited public baths together with the emperor Valerianus. ${ }^{139}$ Tuscus' colleague was Mummius Bassus $\left(P I R^{2}\right.$ $\mathrm{M}$ 702), whose family and further career are unknown. ${ }^{140}$ Unfortunately, no further information on the careers of these Nummii is available to us. Whether Nummius Faus(t)ianus, consul ordinarius in 262 with emperor Gallienus, belonged to the same gens cannot be determined. ${ }^{141}$

The Nummii did not disappear from the consular fasti after 284. On the contrary, another Nummius Tuscus, probably the son of the consul of 258, was consul ordinarius in 295 and city prefect in 302/303; several other Nummii held consulates and proconsulships in the course of the fourth century. ${ }^{142}$

135 On this, see Alföldy (1968), 129; 138; 148.

136 This date is suggested by Peachin (1996), 101.

137 See Alföldy (1982), 363.

138 The identity of his consular colleague is unclear: two inscriptions read 'Alboni II et Maximo, while all other sources mention Albinus and Dexter as consuls for 263. Confusion with the consuls of 227, Albinus and Maximus, is unlikely, since no inscription of 227 gives an iteration number for Albinus. No other consulship of an Albinus and a Maximus is known. Therefore, the two inscriptions probably belong to 263 (when two fasti, Chronogr. a. 354, and Fasti Heracliani, give the iteration number of Albinus). Maximus thus seems to have been consul in 263; whether he is identical with Dexter, preceded him or replaced him is uncertain. See PLRE I, Maximus 1, with further references.

139 HA, Vita Aurel., 13, 1.

140 See Christol (1986), 99. Dietz (1980), 191, has suggested that this Mummius Bassus may have been related to L. Mummius Felix Cornelianus $\left(P I R^{2} \mathrm{M} 703\right)$, consul ordinarius 237, and to L. Mummius Maxi[mus] Fa[us]tinianus ( $\left.P I R^{2} \mathrm{M} 706\right)$, vir clarissimus et patricius, but as far as I can tell the assumption is not supported by any evidence.

141 Christol (1986), 103.

142 See Settipani (2000), 384-387. Jacques (1986), 170, points out that the Nummii established relations with the gens C(a)eionia, which flourished at the end of the third and in most of the fourth century AD. 
Table E13. The Pollieni/Pollenii ${ }^{143}$

$\begin{array}{ll} & \text { (Ti.?) Pollienus Auspex maior }\left(P^{2} R^{2} \text { P 537) }\right. \\ \text { Cursus honorum } & - \text { Consul suffectus } 170 / 175 \\ & - \text { Legatus Aug pr pr Dalmatiae 173/175 } \\ & - \text { Iudex ex delegatione Caesarum 176/180 } \\ & - \text { Praefectus alimentorum (viarum) Appiae et Flaminiae } \\ & \text { ter ca. } 180 \\ & - \text { Proconsul Africae ca. 180/ } 200 \\ & -(\text { Legatus Moesiae Inferioris?? 193/ 197)?? } 144 \\ & - \text { Father of (Ti.?) Pollienus Auspex minor, consul } \\ & \text { suffectus ca. } 185 \text { ? } \\ \text { Notes } & \text { Probably grandfather of Iulius Pollienus Auspex, consul } \\ & \text { suffectus } 212 / 222 .\end{array}$

Cursus honorum - Consul suffectus before 193?, ca. 185 ? 145

(Ti.?) Pollienus Auspex minor $\left(P^{2} R^{2} \mathrm{P} 538\right)$

- Iudex ex delegatione Caesaris/vice Augg cognoscens 197-202? or ca. 218-219? ${ }^{146}$

- Legatus Aug pr pr Hispaniae Tarraconensis 186/189, $193 / 197$ ?, or $222 / 235$ ?

- Legatus Aug pr pr Daciae ca. 190/192, or 193/197?, or $222 / 235$ ?

- Legatus Aug pr pr Moesiae Inferioris 193/197?, or $222 / 235$ ?

- Legatus Aug(g?) pr pr Britanniae ca. 193/197?, or $198 / 200$, or ca. $230^{147}$

${ }^{143}$ See $P I R^{2}$, pars VI, 235, for a stemma.

144 As suggested by several scholars. See Peachin (1996), 95, with further references.

145 Confusion and discussion abound about which positions should be asigned to this man and which to his homonymous father. Here I adopt the opinion of Eck which can be found in $D N P$, vol. 10, s.v. Pollenius. According to him, Pollienus maior (PIR ${ }^{2}$ P 537) was consul suffectus, legatus consularis of Dalmatia, judge vice Caesaris, praefectus alimentorum viae Appiae et Flaminiae ter and proconsul Africae during the reign of Marcus Aurelius and Commodus (and possibly also legatus Moesiae Inferioris under Septimius Severus). He was also the one who was XVvir sacris faciundis in AD 204. Pollienus minor (PIR $\left.{ }^{2} \mathrm{P} 538\right)$ was his son and he was also consul suffectus and judge vice Caesaris. Besides that, he held some positions as governor between 193 and 197 or during the reign of Severus Alexander. For other opinions about their careers, see Leunissen (1989); Peachin (1996), 93-96; Thomasson (1996), 76; Birley (2005), 350. According to $P I R^{2} \mathrm{P} 538$, the start of his career should be dated somewhat earlier, at the end of the reign of Commodus: consul ca. 185, governor of Hispania between 186 and 189 and governor of Dacia between 190 and 192.

146 According to Peachin (1996), 93-96, this position was held during Septimius Severus' absence from Rome between 198 and 202. However, Birley (2005), 350, thinks the tenure of office should be dated ca. 218-219 or even later, during the years from 232 onwards.

147 According to Birley (2005), 350, Pollienus minor governed Britannia Superior, not 
Notes

Cursus honorum

Notes

Notes
- Son of Pollienus Auspex maior, consul suffectus $170 / 175$.

- Perhaps father of Ti. Iulius Pollienus Auspex $\left(P I R^{2}\right.$ $P$ 539), consul suffectus $212 / 222$. It has also been suggested that he may have been identical with Iulius Pollienus Auspex. ${ }^{148}$

- Probably adoptive father of Pollenius Armenius Peregrinus, consul ordinarius 244.

Ti. Iulius Pollienus Auspex ( $P I R^{2}$ P 539)

Cursus honorum - Legatus Aug prpr Numidiae 212/ 222

- Consul suffectus (in absentia) 212/222

- Perhaps the son of Pollienus Auspex minor, consul suffectus ca. 185?, or identical with this man.

Ti. Pollenius Armenius Peregrinus ( $P^{2} R^{2}$ P 536)

- Proconsul Lyciae et Pamphyliae ca. 243

- Consul ordinarius 244 with Fulvius Gavius Numisius Aemilianus

- Proconsul Asiae??149

- Probably son of L. Armenius Peregrinus (PIR A 1059), praetor and frater Arvalis in 213.

- Probably adopted shortly after 220 by Pollienus Auspex minor, consul suffectus ca. 185 ?.

- Perhaps older brother of Armenius Titianus $\left(P I R^{2}\right.$ A 1060), frater Arvalis in 240.

The Pollieni (or Pollenii), probably from Italy, reached consular status in the 170s AD when Pollienus Auspex maior was appointed governor of the consular province of Dalmatia under Marcus Aurelius. ${ }^{150}$ His homonymous son presumably held a suffect consulship at the end of the reign of Commodus. Both of them served as iudices ex delegatione Caesaris, judicial deputies of the emperor in Rome. Pollienus maior seems to have held this position when Marcus and Commodus were fighting the Germans and Sarmatians. When Pollienus minor was iudex is subject to debate: it was either under Commodus, during the reign

\footnotetext{
the undivided province. Furthermore he thinks the position should be dated to the reign of Severus Alexander, circa 230. Eck, DNP, vol. 10, s.v. Pollenius, however, argues that the fact that there is no mention of Inferior or Superior supports the conclusion that this position should be dated between 193 and 197. In $P I R^{2} \mathrm{P} 538$ the position in Britain is dated somewhat later, between 198 and 200.

148 On both suggestions, see $P I R^{2} \mathrm{P}_{53} 8$ with further references.

149 See Eck (1983), 855.

150 Provincial origins for the gens cannot be excluded. On the subject of their geographical origin, see PIR ${ }^{2}$ P 537; Birley (2005), 350-351.
} 
of Septimius Severus, or even under Severus Alexander. ${ }^{151}$ After his judicial service, the father was praefectus alimentorum in Rome thrice and governor of Africa. Perhaps he was also governor of Moesia Inferior at the start of the reign of Septimius Severus. The son was sent to govern several provinces with legions stationed in it. The influential position of Pollienus maior becomes clear from a passage of Dio, which states that Pollienus Sebennus, a nephew of Pollienus maior, was granted mercy through the mediation of his uncle, who apparently even was in a position to mock Septimius Severus at his self-adoption into the house of Marcus Aurelius. ${ }^{152}$

Two more generations of the gens appear in the consular fasti. Iulius Pollienus Auspex, consul suffectus in absentia between 212 and 222, seems to have been Pollienus Auspex minor's son and was probably the adoptive father of Pollenius Armenius Peregrinus, consul ordinarius in 244. The latter married a daughter of Flavius Iulius Latronianus, city prefect under Gordianus III. His consular colleague was Fulvius Gavius Numisius Aemilianus, of the gens Fulvia Aemiliana.

Thus, the Pollieni belonged to the senatorial inner circle throughout the first half of the third century AD. However, after the 240 s they seem to have disappeared from the consular fasti. There is no indication that they attained patrician status.

Table E14. The Pomponii ${ }^{153}$
Cursus honorum
C. Pomponius Bassus Terentianus $\left(P^{2} \mathrm{P}^{2} \mathrm{70}\right)$
- Quaestor provinciae
- Curator rei publicae [Aq/Ur]vinatum
- Legatus Aug/Iuridicus per provinciam Hispaniam Citeriorem (?) ca. 185
- Proconsul Lyciae et Pamphyliae 186/187? ${ }^{\text {154 }}$
- Legatus Aug pr pr Pannoniae Inferioris 187/189?
- Praefectus aerarii militaris 190?-192?

\footnotetext{
151 According to Birley (2005), 350, this position should be dated ca. 218-219 or even later, during the years from 232 onwards. Peachin (1996), 93 and 96, however, thinks that Pollienus minor was iudex during Septimius Severus' absence from Rome between 198 and 202.

152 Dio 77, 9, 2-4. Senator Pollienus Sebennus (PIR $\left.{ }^{2} \mathrm{P} 540\right)$ was aedilis in 205 and was accused in the senate after his governorship in Noricum (AD 205/206) by his successor A. (P. Catius) Sabinus (PIR ${ }^{2}$ C 571).

153 Stemmata appear in $P I R^{2}$, pars VI, 310, and Settipani (2000), 259, but the exact family ties are very uncertain.

154 Leunissen (1989), 278 and 301.
} 
Notes

\section{Cursus honorum - Consul ordinarius 211 with Terentius Gentianus \\ - Legatus Aug pr pr Moesiae (Superioris or Inferioris)?? $212 / 217^{157}$ \\ Notes \\ Pomponius Bassus (PIR $\left.{ }^{2} \mathrm{P} 700\right)$$$
212 / 217^{157}
$$ \\ - Probably son of C. Pomponius Bassus Terentianus, consul suffectus ca. 193 ?. \\ - Probably father of the Bassus (PIR ${ }^{2}$ P 701) who was his lieutenant when he was governor of Moesia (Dio 79, 21, 2). \\ - Killed by Elagabalus ca. 220 (Dio 80, 5, 1-4). Shortly afterwards, the emperor married Bassus' wife Annia Faustina $\left(P I R^{2}\right.$ A 710$)$.}

Cursus honorum
- Consul suffectus ca. 193 ? $^{155}$

- Probably descendant from T. Pomponius Bassus $\left(P I R^{2}\right.$ $\mathrm{P}$ 705), consul suffectus 94, of L. Pomponius Bassus (PIR ${ }^{2}$ P 704), consul suffectus 118 , and of L. Pomponius Bassus Cascus Scribonianus (PIR $\left.{ }^{2} \mathrm{P} 706\right)$, consul suffectus $138 / 143$.

- Probably the father of (Pomponius) Bassus, consul ordinarius $211 .{ }^{156}$

\section{(Ti./F.) Pomponius Bassus [...]stus (PIR ${ }^{2}$ P 702 ; \\ PLRE I, Bassus 17)}

- Consul 245/250?, or $259^{158}$

- Proconsul (Asiae or Africae) ca. 260?159

- Comes Augusti ca. 268/9?

- Corrector totius (Italiae?) 268/9?

- Praefectus urbi 270/271 160

- Consul II ordinarius 271 with the emperor Aurelianus

155 Leunissen (1989), 151-152, shows no doubt whether it was this Bassus who was consul suffectus in 193. On the identification of praefectus urbi Bassus with this man, see Leunissen (1989), 308, note 12. Eck (1971), 747, however, argues that Pomponius Bassus Terentianus cannot be identified with the Bassus who was consul in 193, nor with the praefectus urbi, since nothing is known about this man's consulship. It is possible that Pomponius Bassus Terentianus was the Bassus, amicus Severi, mentioned by Epitome de Caesaribus 20, 6, although this cannot be determined with certainty either.

${ }^{156}$ Leunissen (1989), 373.

157 It is likely but not entirely certain, that the consul ordinarius of 211 is identical to the legatus Moesiae mentioned in Dio 79, 21, 2.

${ }^{158} P^{P I R}{ }^{2} \mathrm{P} 702$ and PLRE I, Bassus 17, assume that he was consul ordinarius in 259 with Aemilianus, but Christol (1986), 223-224, disagrees and suggests this may be the son of the consul ordinarius 259 .

159 From CIL $6.3836=31747=$ IG XIV, $1076=I G R R$ I, 137 (Roma), we know that he was proconsul. The province which he governed, however, is unknown. PLRE I, Bassus 17, has suggested Africa, but this suggestion cannot be found in Thomasson (1972-1990), vol. I, nor id. (1996).

${ }^{160}$ His name is not mentioned in the Chronogr. a. 354 (ed. Mommsen, Chronica 
Notes

- Probably grandson (or great-grandson) of Pomponius Bassus, consul ordinarius 211. . $^{161}$

- Probably identical with the Bassus who was princeps senatus ca. 268/270 (Epitome de Caesaribus 34, 3).

Pomponius Bassus Terentianus, the first member of the gens Pomponia to reach consular status between $\mathrm{AD} 193$ and 284, was a descendant of several consules suffecti between late first and mid-second centuries AD. While the gens probably had Italic roots, there is no indication that members of it had patrician status. ${ }^{162}$ Terentianus may have been the Bassus who is called amicus Severi in the Epitome de Caesaribus, but besides his consulate, to which he may even have been appointed by Commodus, we do not know of any consular positions held under Severus. ${ }^{163}$

Bassus, consul ordinarius in 211, was probably Terentianus' son. His consular colleague was Terentius Gentianus, a member of the gens Hedia Lolliana. ${ }^{164}$ Only one consular position is known to us: he was governor of Moesia during the reign of Caracalla. He never had the chance to reach the pinnacle of the senatorial career, since Elagabalus killed him ca. 220. Soon afterwards, the emperor took Bassus' wife Annia Faustina as his third wife. ${ }^{165}$

The gens disappeared from the consular fasti for only one generation. Circa 260, Pomponius Bassus ... stus became proconsul of either Asia or Africa. Whether he is identical with the Bassus who was consul ordinarius in 259 is not certain, but he must have held a consulate before his proconsular appointment. Later, Bassus ... stus was both comes Augusti, probably under Gallienus, and city prefect under Aurelianus, who was also his consular colleague during his second consulate in 271 , by which

\footnotetext{
Minora I), so he probably held the position briefly within a year; perhaps between Flavius Antiochianus and Postumius Varus in 270, or between Varus and Antiochianus' second term as city prefect in 271. See PLRE I, Bassus 17.

${ }^{161} \mathrm{He}$ either was the son of (Pomponius) Bassus $\left(P^{2} R^{2} \mathrm{P} 701\right)$, tribunus militum in Moesia, or the son or grandson of Pomponia Ummidia $\left(P I R^{2} \mathrm{P} 781\right)$, who was a daughter or granddaughter of Pomponius Bassus, consul ordinarius 211, and of Annia Faustina. Pomponia Ummidia was the wife of Flavius Antiochianus $\left(P I R^{2} \mathrm{~F} 203\right)$, consul II ordinarius 270.

162 On the origin of the gens, see Leunissen (1989), 357.

163 Epitome de Caesaribus 20, 6.

164 According to Settipani (2000), 259, Bassus and Terentius Gentianus were brothersin-law.

165 Dio 80, 5, 1-4.
} 
point he seems to have been princeps senatus. ${ }^{166}$ Besides this, he was probably related to Flavius Antiochianus, city prefect in 270 . No further members of the gens Pomponia are known to us after 271.

Table E15. The Postumii ${ }^{167}$

(T. Fl.) Postumius Varus (PIR ${ }^{2} \mathrm{P}$ 90o/PLRE I, Varus

2)

\begin{tabular}{|c|c|}
\hline \multirow[t]{2}{*}{ Cursus honorum } & $\begin{array}{l}\text { - Legatus legionis II Augustae (Britannia) } 240 / 250^{168} \\
\text { - Consul suffectus ca. } 250^{169}\end{array}$ \\
\hline & - Praefectus urbi 271 \\
\hline Notes & $\begin{array}{l}\text { - May have been descendant (great-grandson?) of } \\
\text { M. Postumius Festus (PIR } R^{2} \text { 886), consul suffectus 160, } \\
\text { and of T. Flavius Titianus, praefectus Aegypti 126-133 } \\
\left(P I R^{2} \text { F } 385 ; 386\right) .{ }^{170}\end{array}$ \\
\hline & $\begin{array}{l}\text { - Probably related to (brother or uncle?) T. Flavius } \\
\text { Postumius Titianus (PIR } \mathrm{P} \text { 899), proconsul Africae }\end{array}$ \\
\hline & \\
\hline & $\begin{array}{l}\text { - Related to (brother or uncle?) Postumius Quietus (PIR } \\
\text { P 890), consul ordinarius } 272 .{ }^{172}\end{array}$ \\
\hline & $\begin{array}{l}\text { - Probably related to Postumius Suagrus, praefectus urbi } \\
275 .{ }^{173}\end{array}$ \\
\hline & $\begin{array}{l}\text { - There may have been another T. Flavius Postumius } \\
\text { Varus, who was this man's son. }{ }^{74}\end{array}$ \\
\hline
\end{tabular}

(T. Fl.) Postumius Quietus (PIR ${ }^{2}$ P 89o/PLRE I, Quietus 2)

Cursus honorum - Quaestor candidatus

- Praetor candidatus tutelarius

- (Legatus pr pr/proconsulis) Asiae??

\footnotetext{
166 Epitome de Caesaribus 34, 3.

167 See Settipani (2000), 373, for a stemma.

168 The date is based on Christol (1986), 193-194.

169 Based on an interval of about twenty years between consulate and city prefecture. See Christol (1986), 194.

${ }^{170}$ Settipani (2000), 371-373, portrays Pomponius Festus was a great man in the age of the Antonines and a friend of Fronto. See Christol (1986), 195 note 6; Birley (2005), 362 .

171 According to Christol (1986), 195, it is unlikely that Postumius Titianus was his brother, because of the considerable difference in age. Birley (2005), 362, suggests that Postumius Titianus may also have been his uncle. Settipani (2000-2002), addenda II, 78, holds that Quietus and Postumius Titianus were brothers, based on CIL 6.41224 (Roma).

172 Birley (2005), 362.

173 Birley (2005), 362, note 112.

174 Christol (1989) 195; Settipani (2000), 371-373.
} 
Notes

Cursus honorum

Notes
- Curator rei publicae Aeclanensium (item Oc) riculanorum

- Curator viae [...] et alimentorum

- Consul ordinarius 272 with (Iunius) Veldumnianus

- Brother or cousin of Postumius Varus, consul suffectus ca. 250.

- Related to (older brother?) T. Flavius Postumius Titianus, consul II ordinarius 301.

- Related to Postumius Suagr(i)us, consul suffectus before 275.

Postumius Suagr(i)us (PIR ${ }^{2}$ P 896/PLRE I, Suagrus)

- Consul suffectus before 275?

- Praefectus urbi 275

- Related to Postumius Varus, consul suffectus ca. 250; Postumius Quietus, consul ordinarius 272; and Postumius Titianus, consul II ordinarius 301.

The third-century (Flavii) Postumii may have descended on the one hand from the Numidian orator and philosopher Postumius Festus from Cirta, who was consul suffectus in 160, and on the other hand from eques Flavius Titianus, governor of Egypt under Hadrianus. Flavius Titianus probably fathered Flavius Claudius Sulpicianus, consul suffectus circa 170 and later proconsul Asiae (186). Sulpicianus' daughter, Flavia Titiana, was the wife of emperor Pertinax, who appointed his father-in-law as city prefect in 193. It seems that Flavius Sulpicianus was executed in 197, perhaps after he supported Clodius Albinus. Apparently, this did not harm the reputation of his offspring, since his son Flavius Titianus was made consul suffectus circa 200. He married Postumia Varia, descendant of Postumius Festus, and the third-century consular Postumii seem to have been their descendants.

Whether Postumius Varus, consul suffectus ca. 250 was a patrician cannot be determined, but Postumius Quietus who was both quaestor and praetor as candidate of the emperor, seems to have had patrician status. ${ }^{175}$ After some praetorian curatorships, he finally held an ordinary consulate in 272 , the year after Varus held the city prefecture of Rome. Quietus' consular colleague was (Iunius) Veldumnianus, of whom it has been suggested that he was a descendant of the emperor Trebonianus

175 Christol (1986), 195, note 6, asserts that Postumius Varus was probably not a patrician. The Postumii are not mentioned in the list of patricians of Jacques (1986), 122123, either. 
Gallus. ${ }^{176}$ In 275, Postumius Suagr(i)us, another member of the gens, was praefectus urbi.

Most likely also belonging to the gens was the patrician Flavius Postumius Titianus ( $P I R^{2} \mathrm{P} 899$ ), consul iterum in 301, whose career started at the very end of the period under discussion and whose consular career took place after $284 .{ }^{177}$ No members of the gens are known to us who held consular positions after Titianus, so the family's glory seems to have peaked in the (second half of the) third century.

Table E16. The Valerii ${ }^{178}$

$\begin{array}{ll} & \text { L. Valerius Messalla Thrasea Priscus }(P I R \text { V } 95)^{179} \\ \text { Cursus honorum } & - \text { Consul ordinarius } 196 \text { with Domitius Dexter } \\ \text { Notes } & - \text { Curator aquarum?? ca. } 198^{180} \\ & - \text { May have been a descendant of the old republican and } \\ & \text { patrician gens of the Valerii Messallae. }{ }^{181} \\ & - \text { Related to (father of?) L. Valerius Messal(l)a } \\ & \text { Apollinaris, consul ordinarius } 214 .^{182} \\ & - \text { Executed during the sole reign of Caracalla. }{ }^{183} \\ & \text { L. Valerius Messal(l)a Apollinaris }(\text { PIR V 86) } \\ \text { Cursus honorum } & - \text { Consul ordinarius } 214 \text { with C. Octavius Appius } \\ & \text { Suetrius Sabinus } \\ \text { Notes } & - \text { Proconsul Asiae } 236 / 238^{184} \\ & - \text { Related to (son of?) Valerius Messalla Thrasea Priscus, } \\ & \text { consul ordinarius } 196 . \\ - & \text { Possibly father of L. Valerius Maximus, consul II } \\ & \text { ordinarius } 256 .\end{array}$

176 It has also been suggested that he descended from a group of Etruscan senators. See PLRE I, Varus 3; Christol (1986), 207; Settipani (2000), 355.

177 Flavius Postumius Titianus was quaestor candidatus; praetor candidatus; consul suffectus/adlectus inter consulares (before 291); corrector Italiae Transpadanae cognoscens vice sacra/electus ad iudicandas sacras appellationes (291/2?); corrector Campaniae (292/3?); consularis aquarum et Miniciae; proconsul Africae (295/6); consul II ordinarius (301); praefectus urbi (305-306). On Titianus' relationship with the other Postumii, see PLRE I, Titianus 9 and Christol (1986), 125; 195; 238 with further references.

178 For stemmata, see Settipani (2000), 224; 240.

179 Settipani (2000), 220, calls him L. Valerius Messala Thrasea Paetus.

${ }^{180}$ Leunissen (1989), 316, note 52.

${ }^{181}$ Leunissen (1989), 109.

182 Leunissen (1989), 109.

183 Dio 78, 5, 5; Leunissen (1989), 402.

184 SEG 26 (1976-1977) 1261 = IEph 4.1107 (Ephesus). According to Dietz (1980), 247, note 704 , this man was identical with Valerius Messalla (Apollinaris?), consul ordinarius 214. However, because of the interval of at least 21 years between the consulship and 


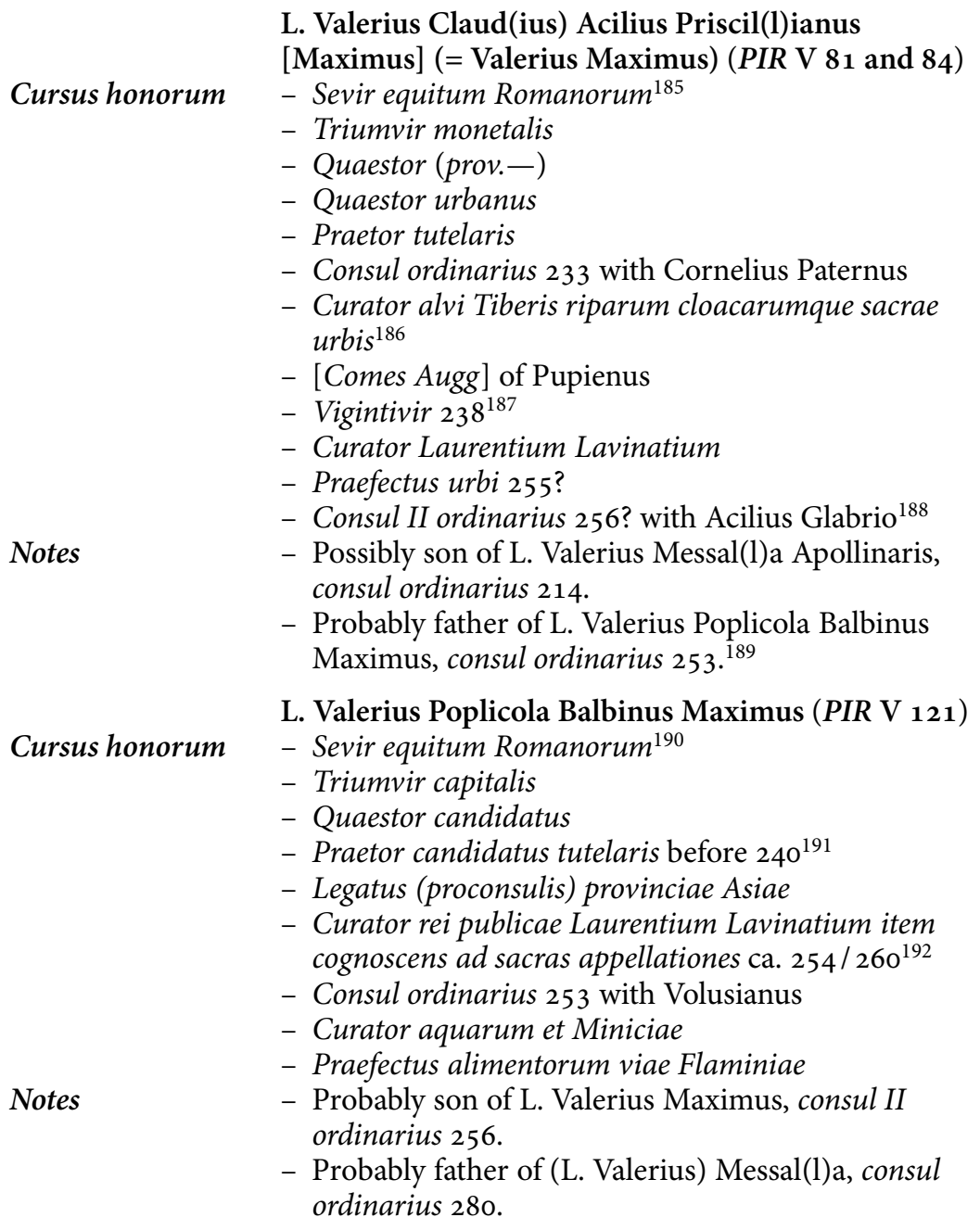

the proconsulship, Eck (1977), 231-233, has suggested that the proconsul of Asia was perhaps a younger brother of the consul ordinarius of 214 or that the long interval might have been caused by exceptional political circumstances.

185 See Körner (2002), 255-256, for a recent discussion of his career.

186 Leunissen (1989), 318.

187 Dietz (1980), 329-331.

188 The offices before and after the reign of Philippus Arabs are known to us, but it is noteworthy that we know no details of his career during Philippus' reign.

189 Körner (2002), 356.

190 See Peachin (1996), 123-127, for a recent discussion of his career.

191 Peachin (1996), 124.

192 This date is suggested by Peachin (1996), 124. 


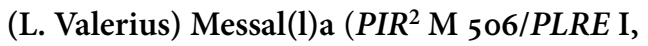
Messalla 1)

$\begin{array}{ll}\text { Cursus honorum } & - \text { Consul ordinarius } 280 \text { with (Vettius) Gratus } \\ \text { Notes } & - \text { Probably grandson of Valerius Messalla Apolinaris, } \\ & \text { consul ordinarius } 214 .{ }^{193} \\ - & \text { Probably son of L. Valerius Poblicola Balbinus } \\ & \text { Maximus, consul ordinarius } 253 .{ }^{194}\end{array}$

The third-century Valerii seem to have had Italic roots. ${ }^{195}$ They behaved as if they were descendants of the republican Valerii Maximi. One was even named after the legendary republican consul Valerius Poplicola. ${ }^{196}$ If the claim was just, the Valerii belonged to a gens which had bred consuls from the republican period into the early Principate. During the early second century not much is heard of the gens, but it reappears in the consular fasti at the end of the second century AD.

Between AD 193 and 284 five members of the gens had consular careers, all holding ordinary consulships. The first to reach a consulship was Valerius Messalla Thrasea Priscus in 196. His colleague was Domitius Dexter, who was consul iterum and one of Septimius Severus' loyal supporters. Dexter held the city prefecture from June 193 onward and perhaps still held it during his second consulship. Hardly anything is known about the further career of Thrasea Priscus. From Dio we learn that Priscus was eventually executed during the sole reign of Caracalla. ${ }^{197}$

The motive for the execution of Priscus remains unclear, but the emperor's grudge was apparently not aimed at the entire gens, since Valerius Messal(l)a Apollinaris, who seems to have been the son of Thrasea Priscus, became consul ordinarius in 214. His colleague was Octavius Appius Suetrius Sabinus, who started a senatorial career under Septimius Severus and was imperial candidatus for the quaestorship and the tribunate (tribunatus plebis). Suetrius Sabinus probably distinguished himself while holding military positions during Caracalla's expedition against the Germans (circa 211-213), first as legatus legionis and later as

\footnotetext{
193 Christol (1986), 116; PLRE I, Messalla 1.

194 According to Kreucher (2003), 200, the Messalla who was consul ordinarius in 253 cannot be identical with Iunius Messalla who is mentioned in the Historia Augusta (Vita Car. 20, 4). He argues that the consul of 253 was probably a member of the Valerii Messallae.

195 Leunissen (1989), 357; 359, suggests that they were from Lavinium (Latium); see also Körner (2002), 356.

196 Dietz (1980), 246; Jacques (1986), 216; Körner (2002), 356.

197 Dio 78, 5, 5 .
} 
praepositus/dux vexillariis against the Alamanni. ${ }^{198}$ After this, Suetrius Sabinus was comes in expeditione Germanica, amicus of Caracalla and consul. ${ }^{199}$ Unfortunately, we are not as well informed on the further career of Valerius Messal(l)a Apollinaris. It is unclear what the course of his career after his consulate was, but it has been suggested that he was proconsul Africae circa 236/238. ${ }^{200}$

Apollinaris' son Valerius Claudius Acilius Priscillianus Maximus reached consular status in 233 under Severus Alexander. His colleague was Cornelius Paternus on whose origin and career we are badly informed. ${ }^{201}$ After his consulate, Valerius Maximus was curator alvei Tiberis, and in 238 he was involved in the senatorial revolt. He was vigintivir and comes of emperor Pupienus. ${ }^{202}$ Much later, under Valerianus, he was made city prefect of Rome and consul iterum. Valerius Maximus' full name leads one to suspect that he was somehow related to the gens Acilia. ${ }^{203}$ It is noteworthy that his consular colleague in 256 was Acilius Glabrio, a member of this gens.

Valerius Maximus may have been the father of Valerius Poplicola Balbinus Maximus, the descendant who was named after Valerius Poplicola. After having been quaestor and praetor as imperial candidatus, and being curator and deputy judge in Italy, he became consul ordinarius in 253 with Volusianus Augustus, son of Trebonianus Gallus. The start of his career

198 See Dietz (1980), 195; Leunissen (1989), 345; 348; Peachin (1996), 106.

199 Dio 79, 13, 2; Peachin (1996), 103. The fact that Suetrius Sabinus' first consulate was ordinary indicates that the emperor held him in high regard, which also comes into view from the other positions that he held under Caracalla after his consulship. Although his career after the death of Caracalla shows some gaps, he still obtained several important positions, resulting in a second ordinary consulship in 240. Hereby, he became the only person who held a second consulship under Gordianus III.

200 Dietz (1980), 246-248; cf. Settipani (2000), 224.

${ }^{201} \mathrm{Cn}$. Cornelius Paternus (PIR ${ }^{2} \mathrm{C}$ 1413) seems to have been proconsul of Africa or Asia and praefectus urbi, but the positions cannot be dated. See Leunissen (1989), 107, note 26.

202 Dietz (1980), 246, calls him a 'Repräsentant des römischen Uradels in der Opposition gegen Maximinus'. Körner (2002), 191; 194; 356, adds that he certainly belonged to the Italian nobility. Leunissen (1989), 116, suggests that Valerius Maximus may have had role in Gordianus becoming emperor in 238 as well. Jacques (1986), 216, suggests that Valerius Maximus may have been related to the emperor Balbinus, considering the name of his alleged son Valerius Poplicola Balbinus Maximus, consul ordinarius in 253.

203 There are two hypotheses on this relationship: (1) Valerius Messalla Apollinaris was perhaps married to a daughter of M'. Acilius Glabrio, consul II ordinarius 186, and thus the mother of Valerius Maximus. (2) Apollinaris was married to a daughter of Ti. Claudius Cleobulus and Acilia Frestana, daughter of Acilius Glabrio, consul II 186, and Valerius Maximus was thus the grandson of this Acilia and great-grandson of Acilius Glabrio. See Settipani (2000), 227-228 with further references. 
suggests that the gens had patrician status. ${ }^{204}$ After his consulship Poblicola Balbinus Maximus remained in Italy and held several offices, though he never reached a proconsulship or a second consulate.

In 280, another Messal(l)a was consul ordinarius. Nowadays, it is assumed that he was member of the gens Valeria, and probably a son of Poplicola Balbinus Maximus. ${ }^{205}$ His consular colleague was (Vettius) Gratus, presumably a member of the gens Vettia. Nothing further is known about the career of this Messal(l)a.

In the fourth century, the Valerii still appear in the consular fasti, but not as frequently and continually as in the third century. ${ }^{206}$

Table E17. The Vettii ${ }^{207}$

$\begin{array}{ll}\text { Cursus honorum } & \text { C. Vettius Gratus Sabinianus (PIR V 331) } \\ & - \text { Sevir equitum Romanorum turmae III } \\ & - \text { Tribunus militum legionis VII Claudiae??208 } \\ & - \text { (Quaestor candidatus?) } \\ & - \text { Praetor candidatus tutelarius } \\ & - \text { Curator viae Flaminiae et alimentorum } \\ & - \text { Consul ordinarius } 221 \text { with M. Flavius Vitellius } \\ & \text { Seleucus } \\ - & \text { Grandson or son of C. Vettius Sabinianus Iulius } \\ & \text { Hospes, consul suffectus ca. } 175 / 176, \text { proconsul Africae } \\ & \text { ca. } 190 / 200 .^{209} \\ - & \text { Probably father of Vettius Gratus Atticus Sabinianus, } \\ & \text { consul ordinarius } 242 .\end{array}$

${ }^{204}$ In view of his career, it is very likely that this Valerius Poblicola Balbinus Maximus had patrician status. According to Leunissen (1989), 378, his father Valerius Maximus was patrician as well.

${ }^{205}$ Kreucher (2003), 200.

206 According to PLRE I, Maximus 48 signo Basilius, and stemma 30 (p. 1147), the Valerius Maximus (signo Basilius) who was praefectus urbi 319-323, descended from L. Valerius Poplicola Balbinus Maximus. Other descendants of the gens may have been the proconsul Africae 319; the praefectus praetorio 327-328, consul 327; and the (Valerius) Maximus who was praefectus urbi 361-362. According to PLRE I, Messalla 2, the Messalla who was consular governor of Pannonia Secunda ca. 374 was also presumably a descendant of Messalla, consul ordinarius 280 . The Messalla who was praefectus praetorio Italiae 399-400 may have been his son and thus another descendant of the Valerii. On the fourth-century Valerii, see also Jacques (1986), 217-218.

207 Stemmata can be found in PIR, vol. 3, 412, and, more recently, in Dietz (1980), 373, stemma 10 and Settipani (2000), 333-335.

${ }^{208}$ CIL 8.823 (Africa Proconsularis) mentions a C. Vettius G[ratus Sa]binianus who was tribunus militum VII Claudiae and quaestor candidatus. According to PIR V 330 this man may have been identical with the consul ordinarius 221.

209 Jacques (1986), 219; Leunissen (1989), 109. 


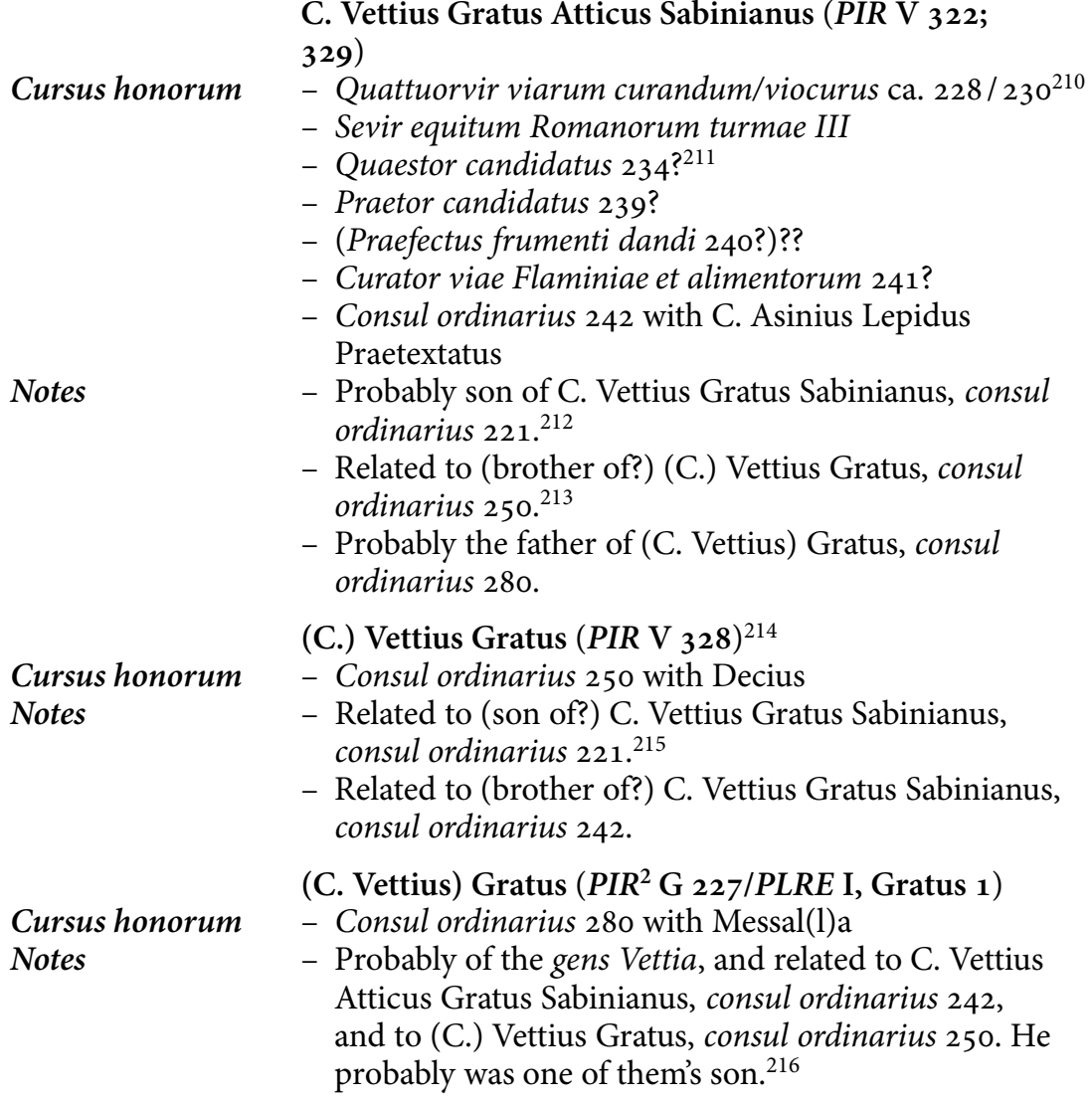

210 See Dietz (1980), 248-251, no. 84, for a discussion of his career.

211 Dietz (1980), 363.

${ }^{212}$ Dietz (1980), 363; Leunissen (1989), 468.

${ }^{213}$ Dietz (1980), 249.

214 According to $P I R^{2}$ S 205, he may have been related to Q. Sattius Flavius Vettius Gratus, consul ordinarius 250. On Q. Sattius Flavius Vettius Gratus, see also PLRE I, Gratus 3, and Kreucher (2003), 200 with further references. This Vettius Gratus restored a sacrarium at Rhegium as corrector (Lucaniae et Bruttii), according to $A E 1923,61$ (Rhegium, Italy). According to PLRE, this man lived late third / early fourth century.

215 Körner (2002), 199/ 200, note 33.

216 Several scholars have argued that this Gratus was related to the Vettii. See PLRE I, Gratus 1; Jacques (1986), 219-220; Kreucher (2003), 200. On the family relations, see also Settipani (2000), 332-335 with further references. 
The origin of the gens Vettia is unknown. ${ }^{217}$ The first Vettius to hold a consulship was Gaius Vettius Sabinianus Iulius Hospes ca. 175/176. Originally an eques, he was accepted in the senatorial order by Antoninus Pius. Iulius Hospes was the son-in-law of Servius Cornelius Scipio Salvidienus Orfitus who was consul in 149/150. Although his nuptial bond with the Scipiones may have been relevant for his status as well, it probably was his successes in the battles against the Germans and his help in suppressing usurper Avidius Cassius that motivated Marcus Aurelius to appoint him consul. After his consulship, he served in several militarily relevant provinces, before serving as governor of Africa at the end of Commodus' reign or the beginning of Septimius Severus. ${ }^{218}$ The Vettii seem to have reached patrician status either before the beginning of the third century or circa $220 / 5.219$

The first consular member of the family in the third century was Vettius Gratus Sabinianus, consul ordinarius in 221. He was the son or, more probably, grandson of Iulius Hospes. ${ }^{220}$ His consular colleague was Marcus Flavius Vitellius Seleucus, on whom we are badly informed. ${ }^{221}$

217 According to Leunissen (1989), 366, they were from Africa (Thuburbo Maius), Italy or Narbonensis. Dietz (1980), 262, argues that they may have had relations with the Gordiani, since they certainly had strong connections with Africa, but admits that this is merely a hypothesis. On their origins, see also Körner (2002), 199.

${ }^{218}$ Iulius Hospes' full career: praefectus cohortis II Commagenorum (CIL 3.1619-7854); tribunus militum legionis I Italicae; translatus in amplissimum ordinem ab imperatore divo Tito Antonino (AE 1920, 45); quaestor; tribunus plebis; praetor; legatus proconsulis Asiae; legatus Aug. ad ordinandos status insularum Cycladum (special appointment); iuridicus per tractus Etruriae Aemiliae Liguriae (under Marcus Aurelius and Lucius Verus); legatus legionis III Italicae concordis (ca. 169); legatus Aug. rationibus putandis trium Galliarum (special appointment, in control of the urban finances); legatus (Aug.) legionis XIV Geminae cum iurisdicatu Pannoniae Superioris; praefectus aerari Saturni (in Rome); legatus Aug. pro praetore Pannoniae Inferioris (169-175, he took part in battle against Germans; donis donatus ab imperatore divo Marco Antonino ob expeditionem Germanicam et Sarmaticam); praepositus vexillationibus ex Illyrico missis ab eodem imperatore ad tutelam urbis (175, the year of Avidius Cassius' usurpation); consul suffectus (ca. 176); curator rei publicae Puteolanorum; curator aedium sacrarum; legatus Augustorum pro praetore Dalmatiae; legatus Augg. pro praetore III Daciarum (ca. 180; Dio 73, 3, 3); legatus Aug. pro praetore Pannoniae superioris (ILS 3655); proconsul Africae (190/191? or at the beginning of the reign of Septimius Severus).

${ }^{219}$ Dietz (1980), 249. According to Jacques (1986), 219-223, Vettius Gratus Atticus Sabinianus, consul ordinarius 242, was probably of patrician status, but Vettius Gratus Sabinianus, consul ordinarius 221, was probably not. He suggests that the gens obtained patrician status sometime between ca. 220/225.

${ }^{220}$ Leunissen (1989), 109.

${ }^{221}$ Leunissen (1989), 368, mentions he was from the Near East, probably Syria, and states (107, note 26$)$ that nothing is known about this man's ancestry. 
That Sabinianus was quaestor and praetor as imperial candidate points to patrician status. Unfortunately, the consular portion of his career is not known to us. He might have died quite soon after his consulship.

The next consular member of the gens was his son, Vettius Atticus Gratus Sabinianus, consul ordinarius in 242. ${ }^{222}$ His colleague, Gaius Asinius Lepidus Praetextatus (PIR A 1230), may have been the son of Asinius Lepidus, probably consul suffectus before $222 / 226 .{ }^{223}$ It has been suggested that Praetextatus was Sabinianus' brother-in-law. ${ }^{224}$ Vettius Gratus, consul ordinarius in 250, may have been Sabinianus' brother. He had the honor of having Decius as his consular colleague.

Exactly thirty years later, in 280 , another Gratus was consul ordinarius. Nowadays it is assumed that he was a member of the gens Vettia. He may have been the son of the consul of 242 or the consul of $250 .{ }^{225}$ His colleague was Messal(l)a, presumably a member of the gens Valeria.

The name 'Vettius' appears in the consular fasti until well into the fourth century and even the sixth century AD; the later Vettii may have descended from the third-century Vettii. ${ }^{26}$

Table E18. The Virii ${ }^{227}$

\section{(L.?) Virius Lupus (PIR V 479)}

Cursus honorum

- Consul suffectus before 196/197

- Legatus Aug pr pr Germaniae Inferioris (dux?) 196?-February 197

- Legatus Aug pr pr Britanniae 197-200?228

\footnotetext{
${ }^{222}$ Leunissen (1989), 468.

223 Settipani (2000), 337.

224 Settipani (2000), 337, asserts that Praetextatus' sister was married to Vettius Atticus Gratus Sabinianus.

225 See PLRE I, Gratus 1; Jacques (1986), 219-220; Kreucher (2003), 200.

226 A Vettius Aquilinus, who seems to have been distantly related through Vettius Sabinianus Iulius Hospes, consul suffectus 176, was consul ordinarius in 286; C. Vettius Cossinius Rufinus was praefectus urbi in 315 and consul ordinarius in 316; Vettius Rufinus was consul ordinarius in 323; Vettius Iustus was consul ordinarius in 328; Vettius Agorius Praetextatus was praefectus urbi in 367; and Gabinius Vettius Probianus was praefectus urbi in 377. They seem to have descended from Vettius Gratus Atticus Sabinianus, consul ordinarius 242. Finally, a Vettius Agorius Basilius Mavortius was consul ordinarius in 527. Whether these men were actually descendants or only claimed genetic lineage cannot be established. For stemmata and further references, see Settipani (2000), 332335 .

${ }_{227}$ For stemmata, see Dietz (1980), 374, stemma 11, and Settipani (2000), 360-362.

228 These dates are based on Leunissen (1989), passim.
} 
Notes

Cursus honorum

Notes

Cursus honorum

Notes
- May have been related to Q. Virius Egnatius Sulpicius Priscus (PIR V 477), who seems to have been consul suffectus during the reign of Septimius Severus or Caracalla. ${ }^{229}$

- Probably father of L. Virius Agricola, consul ordinarius 230, and of L. Virius Lupus, consul ordinarius $232 .{ }^{230}$

\section{Virius Agricola (PIR V 476)}

Cursus honorum - Consul ordinarius 230 with Sex. Catius Clementinus Priscillianus

- Probably son of (L.?) Virius Lupus, consul suffectus before 196/ 197.

- Brother of L. Virius Lupus, consul ordinarius 232.

L. Virius Lupus (Iulianus?) (PIR V 481)

- Sevir equitum Romanorum ${ }^{231}$

- Triumvir capitalis

- Legatus (proconsulis) Lyciae et Pamphyliae

- Allectus inter quaestorios

- Praetor

- Consul ordinarius 232 with L. Marius Maximus

- Legatus Aug Syriae Coelis ?? $238 / 244^{232}$

- Probably son of (L.?) Virius Lupus, consul suffectus before 196/ 197.

- Brother of L. Virius Agricola, consul ordinarius 230.

Vir(i)us Lupus (PIR V 480/PLRE I, Lupus 5)

- Praeses/legatus Aug pr pr Arabiae before 278; 256/9? ${ }^{233}$

- Consul suffectus before 275; 256/259?

- Consularis sacrae urbis regionis II et curator Laurentum Lavinatium

- Consularis regionis II Caelemontium

${ }^{229}$ He may have been identical with the Sulpicius Priscus who was proconsul Asiae during the reign of Severus Alexander, although this man's name may also have been Vibius Sulpicius Priscus. Cf. Thomasson (1972-1990), vol. 1, 235 no. 187. He may have been the uncle of Virius Lupus. On this matter, see Leunissen (1989), 171-172 and 228 with further references. Settipani (2000), 368, calls this man Q. Virius Larcius Sulpicius (Priscus) and links him with Virius Lupus, suffectus 196/197, as well.

230 Birley (1981), 150. According to Jacques (1986), 221, he may also have been their uncle.

231 On his career, see Dietz (1980), 254-256, no. 16.

232 According to Dietz (1980), 254-256, the Virius Iulianus mentioned on an inscription from Heliopolis (ILS 9416) which can be dated during the reign of Gordianus III, who seems to have been legatus Syriae Coelis, was probably identical with Virius Lupus, consul ordinarius 232. Jacques (1986), 221-222, however, rejects this suggestion.

${ }^{233}$ On his career and the dates of the positions, see Christol (1986), 263-270, no. 62, and Peachin (1996), 127-129, no. 11. 
Notes

\section{Cursus honorum}

Notes
- Praeses/legatus Aug pr pr Syriae Coelis before 278; $259 / 268$ ?

- Iudex sacrarum cognitionum vice Caesaris per Aegyptum (or Asiam) et per Orientem 270/5, or $276 / 282$

- Consul (II?) ordinarius 278 with the emperor Probus

- Praefectus urbi 278-280

- May have been the grandson or son of L. Virius Lupus, consul ordinarius 232, or the son of Virius Agricola, consul ordinarius $230 .{ }^{234}$

- May have been an ancestor of Lupus, consularis Campaniae 361/3; of Flavius Lupus, consularis Campaniae at the end of the 4 th century; of Virius Lupus, proconsul Africae 337/361; and of Virius Lupus signo Victorius, consularis Campaniae mid-/end of 4 th century. 235

(L.) Virius Orfitus (PIR P 483; PLRE I Orfitus 2) ${ }^{236}$

- Consul ordinarius 270 with Flavius Antiochianus

- Praefectus urbi 273/4

- Probably related to Virius Agricola, consul ordinarius 230; to Virius Lupus, consul ordinarius 232; and to Virius Lupus, consul ordinarius 278. The cognomen Orfitus also appears with the Cornelii Scipiones. ${ }^{237}$

The geographical origins of the gens Viria cannot be established with certainty, but the gentilicium is particularly common in nothern Italy. ${ }^{238}$ The first member of the gens to reach consular rank was Virius Lupus, one of the generals who supported Septimius Severus at the beginning

${ }^{234}$ Kreucher (2003), 200, suggests that he was the (grand)son of the consul of 232; according to PLRE and Dietz, 374, stemma 11, he was the son of the consul of 232. Christol (1986), 270, only mentions that he may have been a descendant of Virius Lupus, governor of Britannia under Septimius Severus.

235 According to PLRE I, Lupus 5.

${ }^{236}$ According to Christol (1986), 132 and 270-272, there were two Virii Orfiti. He thinks Virius Orfitus maior was consul suffectus around 250, praefectus urbi in $273 / 274$ and consul II ordinarius in AD 280. He posits that Virius Orfitus minor, consul ordinarius in 270, was his son. Otherwise, Christol claims, the interval between Orfitus' first consulship and his position as praefectus urbi would have been remarkably short. The other possibility is that there was only one Orfitus, that his consulship of 270 was a second consulship and that this was not mentioned in the epigraphic evidence. This would be strange as well, according to Christol, since it was quite common in the third century that a second consulship and a position as praefectus urbi overlapped.

237 Christol (1986), 110. PLRE I, Orfitus 2, does not mention a relationship with the other Virii.

${ }^{238}$ Birley (1981), 150; Birley (2005), 185. Eck (1985), 188, argues that they may have been from Asia Minor, based on an inscription from Ephesus (IEph. 710B). 
of his reign. He was probably consular governor of Germania Inferior in 196/197, so he must have held a (suffect) consulship prior to that position. In February 197, Virius Lupus acted as general in a batthe against Albinus and was defeated. ${ }^{239}$ Immediately after Severus' victory over Albinus and the British army at Lugdunum, Virius Lupus was sent to govern Britannia, a fairly typical sequence of offices. ${ }^{240}$ The position of the Romans in the north of the province of Britannia was weak when Lupus arrived. Severus would not send anyone to Britannia whom he did not totally trust, especially after the usurpation of Albinus.

General Virius Lupus probably was the father of Lucius Virius Agricola, consul ordinarius in 230, and of Lucius Virius Lupus (Iulianus), consul ordinarius in 232. The gens may have reached patrician status by then. ${ }^{241}$ Agricola's colleague was Sextus Catius Clementinus Priscillianus, who either was the son of Catius Lepidus, consul suffectus ca. 200, or may have been related to Lucius Catius Celer, amicus of Caracalla, consul suffectus ca. 241. ${ }^{242}$ Virius Lupus (Iulianus)' colleague was Marius Maximus, member of the gens Maria and also a descendant of one of Septimius Severus' generals. The consular portion of the careers of these Virii remains unclear to us. According to Jacques, the gens attained patrician status circa 240/250, but he presents no argument for his claim. ${ }^{243}$

Representing the next generation, Vir(i)us Lupus seems to have been a (grand)son of Agricola or Virius Lupus (Iulianus). He probably held a suffect consulship in the 250s, and was appointed judicial deputy of the emperor, probably in Egypt and the East, during the reign of Aurelianus or Probus. It was probably after that position, at the end of the reign of Probus, that Lupus held two senatorial top positions: a second consulship with Probus as his colleague and the city prefecture of Rome.

239 Dio 76, 6, 2. Some scholars assume that he was a general with a special command, but Leunissen (1989), $242 \mathrm{f}$., argues that Dio would not have used the word stratègos in that case. Leunissen thinks it is more likely that Virius Lupus acted as governor who commanded the provincial legions.

240 Leunissen (1989), 242.

241 Generally, patrician status is ascribed to Virius Lupus, consul ordinarius 232. Christol (1986), 133, however, points out that the career of Vir(i)us Lupus, consul (iterum) in 278 , makes it unlikely to assume that the Virii were patrician at that point. Jacques (1986), 222, thinks that patrician status is improperly ascribed to the consul of 232, but mentions the possibility that Virius Lupus, consul in 278 , may have belonged to another branch of the gens.

${ }^{242} \operatorname{Dietz}$ (1980), 122 and 355; Leunissen (1989), 374.

243 Jacques (1986), 122-123. 
The last third-century member of the Virii to reach consular rank was Virius Orfitus in 270. Orfitus' colleague was Flavius Antiochianus, who was consul iterum in 270 and praefectus urbi at the same time. Antiochianus was married to Pomponia Ummidia, member of the gens Pomponia. ${ }^{244}$ Orfitus also held the city prefecture in $273 / 4$.

Although these third-century Virii probably were ancestors of viri consulares of the fourth century, the gens seems to have reached its prime in the third century. ${ }^{245}$

${ }^{244}$ Christol (1986), 110 and 193.

245 A Virius Lupus (PLRE I, Lupus 6) was proconsul Africae between 337 and 361, and some others are mentioned as consulares. On the Virii after 284, see Jacques (1986), 222223. 